\title{
日本のスラブ内地震とプレート境界地震の \\ 水平・上下動の距離減衰式 \\ ATTENUATION RELATIONS OF HORIZONTAL AND VERTICAL GROUND MOTIONS FOR INTRASLAB AND INTERPLATE EARTHQUAKES IN JAPAN
}

\author{
佐 藤 智 美* \\ Toshimi SATOH
}

\begin{abstract}
Vertical motions have been required as input motions to important structures, such as nuclear power plants and base-isolation structures. However, empirical attenuation relations of vertical motions for big intraslab and interplate earthquakes in Japan had not been proposed yet. Therefore in this study we develop attenuation relations for estimating horizontal and vertical ground motions caused by these earthquakes. The relations are provided for peak ground acceleration (PGA), peak ground velocity, and $5 \%$ damped acceleration response spectrum (SA) for radial, transverse, and vertical components. In order to use the relations as input motions we obtain site coefficients at bedrock with different S-wave velocities. The attenuations of horizontal motions in this study obtained from records observed at the fore-arc are smaller than those in the previous ones. The ground motions for big intraslab and interplate earthquakes occurring at the Pacific plate are larger than those at the Philippine Sea plate at most cases. We find that the PGA and the SA in a short period range for intraslab earthquake are larger than those for interplate earthquakes at the same focal depth $D$ and are roughly proportional to $D^{23}$.
\end{abstract}

Keywords : Attenuation relation, Vertical ground motion, Intraslab earthquake, Interplate earthquake, Focal depth 距離减衰式, 上下動, スラブ内地震, プレート境界地震, 震源深さ

\section{1. はじめに}

地震動の応答スペクトルや最大加速度、最大速度の距離減衰式は、 簡便に地震動を推定できる強震動予測手法として、多数の式が提案 され、幅広く使用されている。例えば、最近、米国では、NGA プロ ジェクト例えば1),2)により、主に浅い地殸内地震の記録に基づき水平動 の最大加速度、最大速度、応答スペクトルの距離減衰式が数多く作 成された。しかし、データセットに海溝型地震(本研究では、プレー 卜境界地震とスラブ内地震を含めて海溝型地震と呼ぶ)の記録がほ とんど含まれていないため、プレート境界地震やスラブ内地震の強 震動予測には適していない。他の既往の海溝型地震に適用可能な距 離減衰式も、ほとんどが水平動に対する式である。上下動に対する 高橋・他 ${ }^{3)}$ 、西村・堀家 ${ }^{4)}$ 、堀家・西村 ${ }^{5)}$ の式は気象庁マグニチュ ード $M_{J}$ をパラメータとしているため、モーメントマグニチュード $M w$ が用いられる断層モデルに基づく強震動評価法による結果との 直接の比較がしにくい。また、これらの式 ${ }^{3,4), 5}$ の作成に用いられて いるデータセットの海溝型地震の最大 $M_{J}$ は 7 以下であり、プレー 卜境界地震とスラブ内地震の区別はない。高橋・他 ${ }^{3)}$ の式は、海外 の大規模地震に対しても適用性が確認されているが、海溝型地震の データは東北南部から関東付近に限られている。

一方、最近では、免震構造物の上下動に対する耐震安全性評価の 観点から、構造評定でも適切な上下動評価が求められるようになっ ている。また、2006 年 9 月に、「発電用原子炉施設に関寸る耐震設 計審查指針」が改訂され、水平動のみならず上下動についても、断 層モデルによる強震動評価が盛り込まれるようになった ${ }^{6}$ 。応答ス
ペクトルによる評価も水平動と上下動に対して必要である ${ }^{6}$ 。この ような背景を踏まえ、筆者は先の論文 7で地殼内地震に対する水平 動と上下動の距離減衰式を作成している。スラブ内地震は、地震の 発生場所の特定が困難で、強震動予測レシピといわれる震源パラメ 一夕設定手法も確立してないため、活断層により生じる地款内地震 やプレート境界地震と比較して、断層モデルによる強震動評価の不 確定性が大きい。したがって、スラブ内地震に対する応答スペクト ルの距離減衰式による水平動・上下動の評価は特に重要であると考 えられる。2003 年 5 月 26 日に宮城県沖で発生したスラブ内地震 $\left(M_{J} 7.1\right)$ では、震源近傍で水平動の大加速度記録が観測されたが、後 述のように上下動も K-NET や KiK-net 観測点だけでも 4 地点で $600 \mathrm{~cm} / \mathrm{s}^{2}$ を越え、そのうち 2 地点では $800 \mathrm{~cm} / \mathrm{s}^{2}$ を越えている。この ように、スラブ内地震の地震動には短周期が卓越する場合が多く例元 (゙ 8) 14)、スラブ内地震に対する水平動と上下動の距離減衰式は、構 造物のみならず、機器の耐震安全性評価に有用と考えられる。

観測記録に基づく既往の研究では、スラブ内地震では震源での短 周期の励起が大きいこと例えば 8) 14)の他、プレート境界地震やスラブ 内地震の短周期の励起特性の深さ依存性 ${ }^{10), 11), 14)}$ や太平洋プレートと

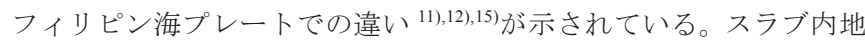
震に対するこれらの特徽は、経験的グリーン関数法に基づき推定さ れた震源モデルの強震動生成領域の応力降下量などでも指摘されて

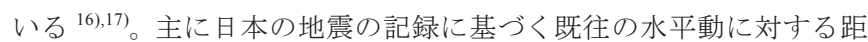
離減衰式の中では、司・翠川 ${ }^{18)}$ の最大加速度・最大速度の式や Zhao et al. ${ }^{19)}$ の応答スペクトルと最大加速度・最大速度の式にスラブ内地

\footnotetext{
$*$ 清水建設侏技術研究所 主任研究員・博士 (工学)

Senior Researcher, Institute of Technology, Shimizu Corp., Dr. Eng.
} 
震とプレート境界地震の区別、震源深さ依存性が取り入れられてい る。本研究では、水平動と上下動の両方に対して、スラブ内地震と プレート境界地震の区別、震源深さ依存性の他、太平洋プレートと フィリピン海プレートの違いを考慮した式を作成する。この際、震 源深さ $D$ をパラメータとした既往の距離減衰式 ${ }^{18), 19)}$ では、回帰係数 を $h$ とすると、地震動レベルと $10^{h D}$ との比例関係が仮定されている が、本研究では後述の解釈に基づき $D^{h}$ との比例関係を仮定した。

本研究の距離減衰式のもうひとつの特徵は、KiK-net 観測記録の はぎとり解析に基づき $\mathrm{S}$ 波速度 $(V s) 3000 \mathrm{~m} / \mathrm{s}$ 程度の地震基盤に対す るサイト係数を求めた点である。これにより、地震基盤からの増幅 率といら絶対量も得られる。また、告示スペクトルの設定位置であ る工学的基盤の条件のひとつが $V s 400 \mathrm{~m} / \mathrm{s}$ 以上の地盤であり、原子力 発電所の基準地震動策定位置である解放基盤の条件のひとつが概ね VS $700 \mathrm{~m} / \mathrm{s}$ 以上の硬質地盤となっている ${ }^{6)}$ 。そこで、Vs $400 \sim 600 \mathrm{~m} / \mathrm{s}$ 、 $600 \sim 800 \mathrm{~m} / \mathrm{s} 、 800 \sim 1000 \mathrm{~m} / \mathrm{s}$ の基盤に対するサイト係数も求めた。 さらに、本研究の距離減衰式は、構造物の耐震安全性評価のための 入力地震動として用いることを主目的としているため、振幅の大き い地点での地震動が重要と考え、火山フロント付近の高減衰領域の 影響を受けない火山フロント前孤側に対する式とした。なお、佐藤 7)の地殼内地震に対する距離減衰式では、Radial 成分と Transverse 成 分に明らかな違いがみられたため、ここでも、水平動は Radial 成分 と Transverse 成分に区別する。また、記録全体(全継続時間)の他、P 波部と S 波部の距離減衰式も佐藤 ${ }^{7)}$ と同様に作成した。

表 1 太平洋プレートの海溝型地震の諸元(気象庁)

\begin{tabular}{|c|c|c|c|c|c|c|c|c|c|}
\hline \multicolumn{3}{|c|}{ 発震時 } & 深さ & $M_{t}$ & 地震名または & $M_{W}$ & $M_{0}$ & 地震夕 & $M_{0}, M_{W}$ \\
\hline 年 & 月/日 & 時：分 & $\mathrm{km}$ & & 震央地名 & & dyne-cm & & \\
\hline 1989 & $11 / 2$ & $3: 25$ & 0.0 & 7.1 & 三陸はるか沖 & 7.4 & $1.36 \times 10^{27}$ & sub & Har. \\
\hline 1993 & $1 / 15$ & $20: 06$ & $109.1^{1}$ & 7.5 & 釧路沖地震 & 7.6 & $3.00 \times 10^{27}$ & sla & 文献 23) \\
\hline 1994 & $10 / 4$ & $22: 22$ & $60.5^{*}$ & 8.2 & 北海道東方沖地震 & 8.2 & $2.60 \times 10^{28}$ & sla & 文献24) \\
\hline 1994 & $12 / 28$ & $21: 19$ & $32.3^{*}$ & 7.6 & 三陸沖地震 & 7.7 & $4.00 \times 10^{27}$ & sub & 文献25) \\
\hline 1995 & $1 / 7$ & $7: 37$ & 47.8 & 7.2 & 岩手県北東沖 & 6.9 & $3.33 \times 10^{26}$ & sub & Har. \\
\hline 1996 & $9 / 11$ & $11: 37$ & 52.0 & 6.4 & 銚子付近 & 6.1 & $1.97 \times 10^{25}$ & sla & Har. \\
\hline 1999 & $5 / 13$ & $2: 59$ & 106.0 & 6.3 & 釧路地方 & 6.1 & $1.72 \times 10^{25}$ & sla & F-net \\
\hline 2000 & $1 / 28$ & $23: 21$ & 58.5 & 7.0 & 根室半島沖 & 6.7 & $1.21 \times 10^{26}$ & sla & F-net \\
\hline 2003 & $5 / 26$ & $18: 24$ & $76.8^{*}$ & 7.1 & 宮城県沖 & 7.1 & $6.50 \times 10^{26}$ & sla & 文献 26) \\
\hline 2003 & $9 / 26$ & $4: 50$ & $40.4^{*}$ & 8.0 & 十勝沖地震 & 8.2 & $2.20 \times 10^{28}$ & sub & 文献 27) \\
\hline 2003 & $9 / 26$ & $6: 08$ & 21.0 & 7.1 & 十勝南東沖 & 7.3 & $1.15 \times 10^{27}$ & sub & F-net \\
\hline 2003 & $9 / 27$ & $5: 38$ & 34.0 & 6.0 & 十勝南東沖 & 6. 0 & $1.16 \times 10^{25}$ & sla & F-net \\
\hline 2003 & $10 / 8$ & $18: 06$ & 51.4 & 6.4 & 十勝南東沖 & 6.6 & $9.83 \times 10^{25}$ & sub & F-net \\
\hline 2003 & $10 / 31$ & $10: 06$ & 33.3 & 6.8 & 宮城県南東沖 & 6.7 & $1.42 \times 10^{26}$ & sub & F-net \\
\hline 2004 & $11 / 29$ & $3: 32$ & 48.2 & 7. 1 & 根室半島沖 & 7. 0 & $3.36 \times 10^{26}$ & sub & F-net \\
\hline 2004 & $12 / 6$ & $23: 15$ & 45.8 & 6.9 & 根窒半島沖 & 6.7 & $1.41 \times 10^{26}$ & sub & F-net \\
\hline 2005 & $8 / 16$ & $11: 46$ & $41.1^{*}$ & 7.2 & 宮城県沖 & 7.1 & $5.62 \times 10^{26}$ & sub & 文献28) \\
\hline 2005 & $9 / 21$ & $11: 25$ & 102.9 & 6.0 & 国後島付近 & 6.0 & $1.23 \times 10^{25}$ & sla & F-net \\
\hline 2001 & $12 / 2$ & $22: 01$ & 121.5 & 6.4 & 岩手県南部 & 6.4 & $5.34 \times 10^{25}$ & sla & F-net \\
\hline 2008 & $5 / 8$ & $1: 45$ & 50.6 & 7.0 & 茨城県はるか沖 & 6.8 & $1.97 \times 10^{26}$ & sub & F-net \\
\hline 2008 & $7 / 19$ & $11: 39$ & 31.6 & 6.9 & 福島県はるか沖 & 6.9 & $2.39 \times 10^{26}$ & sub & F-net \\
\hline 2008 & $7 / 24$ & $0: 26$ & $106.9^{9}$ & 6.8 & 岩手県北部 & 6.9 & $2.89 \times 10^{26}$ & sla & 文献29) \\
\hline 2008 & $9 / 11$ & $9: 20$ & 30.9 & 7.1 & 土勝南東沖 & 6.8 & $1.97 \times 10^{26}$ & sub & F-net \\
\hline
\end{tabular}

表 2 フィリピン海プレートの海溝型地震の諸元(気象庁)

\begin{tabular}{|c|c|c|c|c|c|c|c|c|c|}
\hline \multicolumn{3}{|c|}{ 発震時 } & 媣さ & $M_{J}$ & 地震名または & $M_{W}$ & $M_{0}$ & 地震夕 & $M_{0}, M_{W}$ \\
\hline 年 & 月/旦 & 時：分 & $\mathrm{km}$ & & 震央地名 & & dyne-cm & $17^{* * *}$ & \\
\hline 1996 & $10 / 18$ & $19: 50$ & 37.7 & 6.4 & 種子島付近 & 6.6 & $1.00 \times 10^{26}$ & sub & Har. \\
\hline 1996 & $10 / 19$ & $23: 01$ & 37.0 & 5.5 & 日向灘地方 & 5.7 & $4.16 \times 10^{24}$ & sub & Har. \\
\hline 1996 & $10 / 19$ & $23: 44$ & 34.0 & 6.9 & 日向瀨地方 & 6.7 & $1.43 \times 10^{26}$ & sub & Har. \\
\hline 1996 & $10 / 20$ & $6: 17$ & 37.4 & 5.3 & 日向灘地方 & 5.5 & $2.39 \times 10^{24}$ & sub & Har. \\
\hline 1996 & $12 / 3$ & $7: 17$ & 38.0 & 6.7 & 旦向灘地方 & 6.7 & $1.23 \times 10^{26}$ & sub & Har. \\
\hline 1997 & $3 / 16$ & $14: 51$ & 39.1 & 5.9 & 愛知県北東部 & 5.6 & $2.97 \times 10^{24}$ & sla & $F-n e t$ \\
\hline 1998 & $12 / 16$ & $9: 18$ & 24.1 & 5.6 & 大隅半島南東沖 & 6.1 & $1.85 \times 10^{25}$ & sla & F-net \\
\hline 1999 & $1,1 / 24$ & $9: 37$ & 40.0 & 6.6 & 種子鳥付近 & 6.5 & $6.58 \times 10^{25}$ & sla & F-net \\
\hline 1999 & $8 / 21$ & $5: 33$ & 65.8 & 5.5 & 和歌山県中部 & 5.6 & $2.79 \times 10^{24}$ & sla & F-net \\
\hline 2000 & $6 / 25$ & $15: 34$ & 36.0 & 6.0 & 大隅半島南東沖 & 6.0 & $1.13 \times 10^{25}$ & sub & $\mathrm{F}-$ net \\
\hline 2001 & $3 / 24$ & $15: 27$ & 46.5 & 6.7 & 芸予地震 & 6.9 & $2.98 \times 10^{26}$ & sla & 文献30) \\
\hline 2001 & $4 / 25$ & $23: 40$ & 39.3 & 5.7 & 旦向灘地方 & 5.7 & $4.00 \times 10^{24}$ & sla & $F$-net \\
\hline 2002 & $11 / 4$ & $13: 36$ & 35.2 & 5.9 & 日向灘地方 & 5.6 & $3.64 \times 10^{24}$ & sla & $\mathrm{F}-\mathrm{net}$ \\
\hline 2004 & $9 / 5$ & $19: 07$ & $19.2^{*}$ & 7.1 & 紀伊半島南東沖 & 7.3 & $9.80 \times 10^{26}$ & sla & 文献31) \\
\hline 2004 & $9 / 5$ & $23: 57$ & $15.2^{*}$ & 7.4 & 紀伊半島南東沖 & 7.4 & $1.80 \times 10^{27}$ & sla & 文献31) \\
\hline 2004 & $9 / 6$ & $5: 30$ & 36.9 & 5.9 & 紀伊半島南東沖 & 5.7 & $3.82 \times 10^{24}$ & sla & $F$-net \\
\hline 2004 & $9 / 7$ & $8: 29$ & 41.0 & 6.5 & 紀伊半島南東沖 & 6.5 & $6.00 \times 10^{25}$ & sla & F-net \\
\hline 2005 & $5 / 31$ & $11: 04$ & 28.6 & 5.8 & 天隅半島南東沖 & 5.7 & $4.38 \times 10^{24}$ & sub & F-net \\
\hline 2006 & $3 / 27$ & $11: 50$ & 34.8 & 5.5 & 日向灘地方 & 5.5 & $2.12 \times 10^{24}$ & sla & $F-n e t$ \\
\hline
\end{tabular}

\section{2. データ}

1988 年〜2008 年 7 月までに海溝型地震が観測されている気象庁 87 型観測点、K-NET 観測点、KiK-net 観測点(地表)の強震記録から、 1)〜5)の条件でデータを選択した。

1) 太平洋プレートのプレート境界地震 : $M w 6.5$ 以上

太平洋プレートのスラブ内地震 : $M w 6.0$ 以上

フィリピン海プレートの海溝型地震 : $M w 5.5$ 以上

2) 断層最短距離 $250 \mathrm{~km}$ 以下

3) 震源深さ $130 \mathrm{~km}$ 以下

4) $M w$ をパラメータとした福島・田中 ${ }^{20)}$ の距離減衰式で、水平動 の最大加速度が $15 \mathrm{~cm} / \mathrm{s}^{2}$ 以上となる距離以内の観測点

5) 東北地方から関東にかけて存在する火山フロントと九州の火 山フロントの前弧側の観測点

5)の条件は、火山や火山フロント付近の浅い部分に高減衰(LowQ) 領域が存在し例えば14)、深い地震でも火山フロント付近の高減衰領域

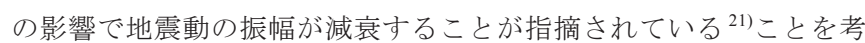
慮したものである。この現象を表現するためには、火山フロントを 境に不連続な距離減衰式が必要となるが、距離減衰式を入力地震動 策定に用いるには地震動の大きい地点での予測が重要であるという 考えに基づき、5)の条件を付けた。また、本研究で用いる回帰分析 手法では、地震も観測点も孤立しているデータが含まれている場合 解くことができないため、この条件を満たす公開観測記録を探し、 建築研究所の広尾町役場の記録をデータセットに加えた。なお、本
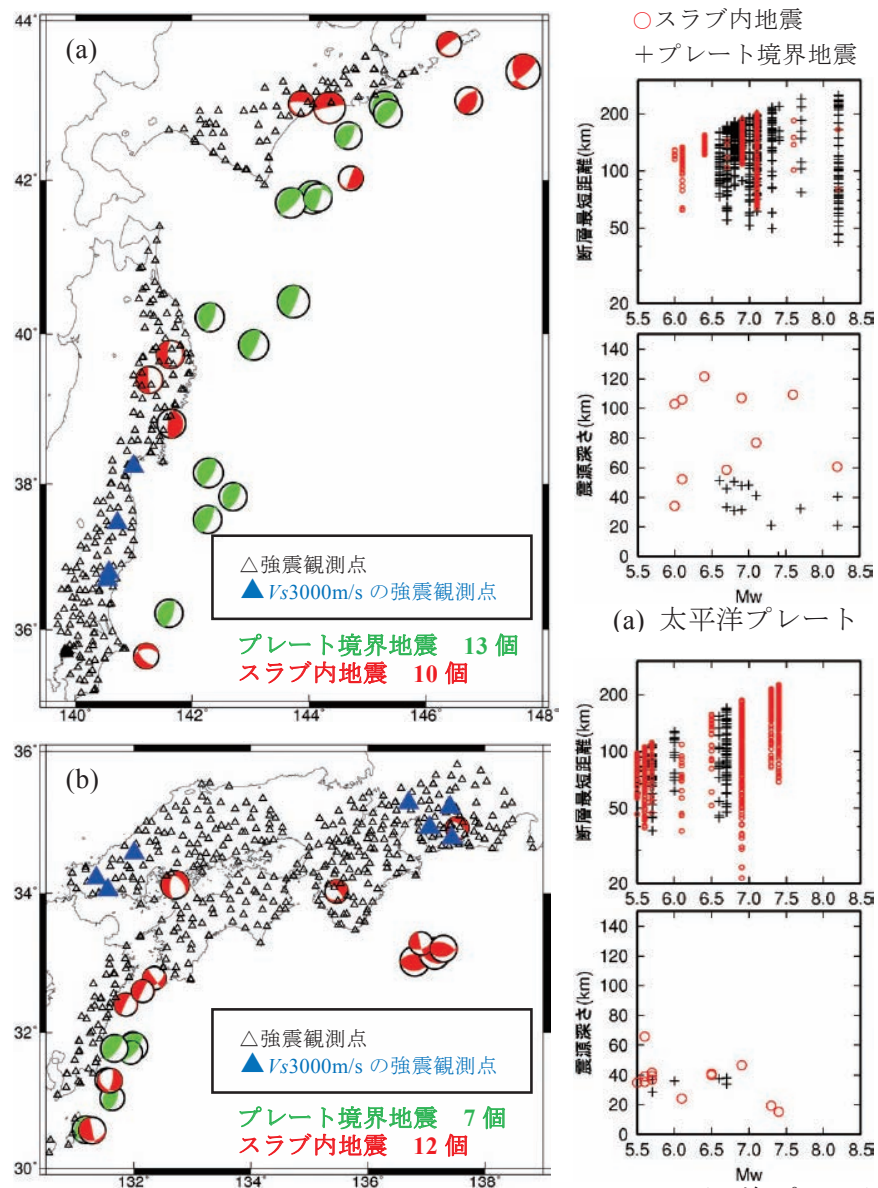

(a) 太平洋プレート

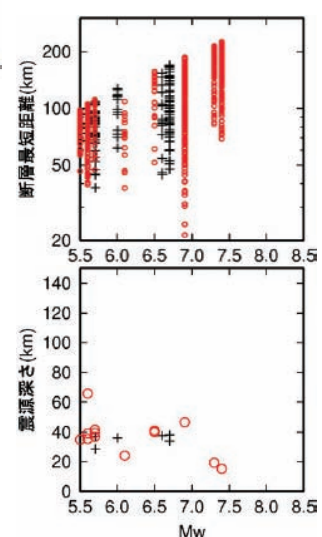

図1 太平洋プレート(a)とフイリピ ン海プレート(b)の海溝型地震の震央 位置・メカニズム解及び観測点位置 (b) フィリピン海プレート

図 $2 M w$ と断層最短距離 $X$ 、震源深さとの関係 
解析手法では、観測点毎のサイト係数が求められ、回帰誤差を算出 する地盤分類毎のサイト係数には広尾町役場の記録を含めていない ため建物の記録であっても問題ない。

表 1、表 2 に、それぞれ、本研究で用いる太平洋プレートとフィ リピン海プレートの地震の諸元を示す。プレート境界地震とスラブ 内地震の区別は、国土地理院発行の地震予知連絡会報に掲載されて いる情報やメカニズム解及び震源深さとプレートの深さ ${ }^{22)}$ の関係に 基づいて行った。表中に示した既往の文献 23) 31)で巨視的断層面が 設定されている地震については、その地震モーメント $M_{0}$ から $M w$ を算出し、その断層面を用いて断層最短距離を計算した。これ以外 の地震については、F-net あるいは Harvard 大学の推定 $M_{0}$ を用い、 気象庁の震源位置からの震源距離を断層最短距離とした。震源深さ は、巨視的断層面が設定されている地震については、巨視的断層面 の中心深さとし、その他は気象庁の震源深さとした。ただし、2001 年芸予地震の巨視的断層面の中心深さはアスペリティの深さ ${ }^{17)}$ と対 応がよくないため、気象庁の震源深さを用いた。なお、予測の際に アスペリティの情報まで必要となると利便性に久けるため、本研究 でアスペリティの深さはパラメータとして用いない。図1に、太平 洋プレートとフィリピン海プレートの地震の震央位置及びメカニズ ム解(F-net あるいは Harvard 大学) と観測点位置を示す。フィリピン 海プレートの地震は、プレート境界地震は日向灘の地震のみ、スラ ブ内地震は日向灘の地震と紀伊半島南東沖の地震がほとんどである ため、これらの地震の特徵が距離減衰式に反映されると考えられる。 選択された KiK-net 観測点のらち、検層結果に $\mathrm{S}$ 波速度 $3000 \mathrm{~m} / \mathrm{s}$ 以 上の地震基盤が存在している地点では、地震基盤での露頭波(はぎと り波)を求めている。図 2 には、データの $M w$ と断層最短距離、震源 深さとの関係を示す。

選択した記録には、佐藤 7) と同様に、0.2 15Hz の帯域フィルター をかけ、記録の全継続時間の他、 $\mathrm{P}$ 波部、 $\mathrm{S}$ 波部のデータセットを 作成した。 $\mathrm{S}$ 波部は、走時が震源距離 $[\mathrm{km}] / 4.2[\mathrm{~km} / \mathrm{s}]+2[\mathrm{~s}]$ となる時間 を $\mathrm{S}$ 波初動到達時間とし、その前に 0.2 秒のコサインテーパをつけ て切り出した。 $\mathrm{P}$ 波部は、 $\mathrm{S}$ 波初動到達時間- $0.2[\mathrm{~s}]$ を $\mathrm{P}$ 波終了時間と し、その後に 0.2 秒のコサインテーパをつけて切り出した。また、 気象庁の震央位置を用いて、水平 2 成分を Radial 成分と Transverse 成分に変換した。地震一観測点ペア数は太平洋プレートの地震では 847、フィリピン海プレートの地震では 421 である。ただし、太平洋 プレートの地震では、P 波部から観測されていない記録も含まれて いるため、 $\mathrm{P}$ 波部のデータ数は全継続時間、 $\mathrm{S}$ 波部よりやや少ない。

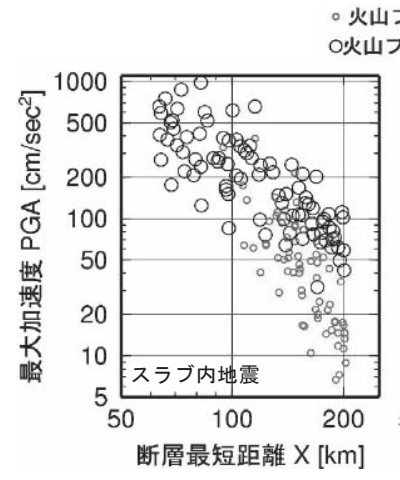

(a) 2003 年宮城県沖地震 $\left(M_{w} 7.1\right)$
。火山フロント背弧側(西)

山コフント前弧側(東)

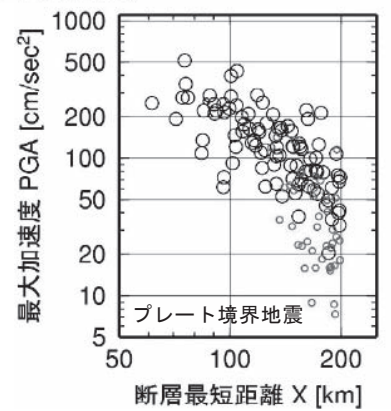

(b) 2005 年宮城県沖地震 $\left(M_{w} 7.1\right)$
図 3 観測最大加速度(Radial 成分)の距離減衰特性

\section{3. 解析方法}

(1) 回帰分析手法

本研究で用いる地震動強さの距離減衰式は、 $M_{w}$ と断層最距離 $X$ $[\mathrm{km}]$ 、震源深さ $D[\mathrm{~km}]$ をパラメータとして次式で表現する。

$\log _{10} Y=a M w+h_{\text {sub }} \log _{10} D+h_{\text {sla }} \log _{10} D$

$$
-b X-\log _{10}\left(X+d 10^{0.5 M w}\right)+c_{J} \pm e
$$

ただし、 $D<10 \mathrm{~km}$ では、 $D=0 \mathrm{~km}$ とする。(1)式で、 $Y$ は $\mathrm{P}$ 波部、 $\mathrm{S}$ 波 部、全継続時間のそれぞれ 3 成分に対する最大加速度 $\left[\mathrm{cm} / \mathrm{s}^{2}\right]$ 、最大 速度 $[\mathrm{cm} / \mathrm{s}]$ 、減衰定数 $5 \%$ の加速度応答スペクトル $\left[\mathrm{cm} / \mathrm{s}^{2}\right]$ である。加 速度応答スペクトルを計算する固有周期 $T$ は、 $\mathrm{S}$ 波部と全継続時間 の場合は 0.07〜 5.0 秒、近距離のデータの継続時間が短い $\mathrm{P}$ 波部の 場合は $0.07 \sim 1.0$ 秒である。 $a 、 h_{s u b} 、 h_{s l a} 、 b 、 d 、 c_{J}$ は回帰係数であ り、e は標準偏差(回帰誤差)である。(1)式では、スラブ内地震とプ レート境界地震の距離減衰を同じと仮定したことになる。この仮定 の妥当性を示すために、スラブ内地震である 2003 年宮城県沖地震 $\left(M_{w} 7.1\right)$ とプレート境界地震である 2005 年宮城県沖地震 $\left(M_{w} 7.1\right)$ の Radial 成分の最大加速度の距離減衰を図 3 に示寸。火山フロント前 弧側のデータをみると、距離減衰の傾きは両者でほぼ同じであるこ とがわかる。スペクトルインバージョンに基づく $Q$ 值でも同様の傾 向が得られている ${ }^{32)}$ 。d $10^{0.5 M w}$ は震源近傍で地震動の振幅が頭打ちす る現象を表現する項である例えば 18)。本研究で用いるデータセットに は震源近傍の記録が少なく $d$ の推定が困難であることから、地殼内 地震から推定された ${ }^{7)} d$ を用いた。 $h_{\text {sub }}$ はプレート境界地震に対する 回帰係数であり、スラブ内地震に対しては 0 である。同㥞に、 $h_{s l a}$ はスラブ内地震に対する回帰係数であり、プレート境界地震に対し ては 0 である。このモデル化により、プレート境界地震とスラブ内 地震の地震動の深さ依存性の違いが考慮できる。震源深さ $D$ をパラ メータとした既往の距離減衰では、 $\log _{10} Y$ が $D$ と線形関係となって いるが、本研究では、以下のような解釈に基づき、 $\log _{10} Y$ が $\log _{10} D$ と線形関係の式としている。

加速度応答スペクトルは、振幅の大きい周期範囲では、フーリエ スペクトルと類似の形状をもつ。そこで、 $\omega^{-2}$ モデル ${ }^{33}$ に基づいて考 えると、震源に関連する応答スペクトルは本研究で対象とした周期 の大部分の短周期領域で短周期レベルに比例する。また、短周期レ ベルは $M_{0}$ の $1 / 3$ 乗と $\mathrm{Brune}^{33)}$ の応力降下量 $\Delta \sigma$ の 2/3 乗に比例する。 一方、Coulomb-Mohr の式では、有効法線応力 $\sigma_{n}^{\text {eff }}$ はせん断強度 $\tau$ と、

$\tau=\tau_{0}+\mu \times \sigma_{n}^{e f f}=\tau_{0}+\mu \times\left(\sigma_{n}-P\right)$

の関係がある。ここで、 $\mu$ は摩擦係数、 $\sigma_{n}$ は法線応力、 $P$ は間隙水 圧、 $\tau_{0}$ は凝着力 $\left(\right.$ 粘着力)である。法線応力 $\sigma_{n}$ が $D$ に比例し、間隙水 圧が静水圧的に作用し、摩擦係数が一定と仮定すると、脰 $D$ に比 例すると考えることができる。そして、 $\Delta \sigma$ との線形関係を仮定す ると、 $\Delta \sigma[\mathrm{MPa}]$ を $D[\mathrm{~km}]$ を用いて以下の式で表わすことができる。

$$
\Delta \sigma=p+q \times D
$$

ここで、 $p 、 q$ は定数である。 $\mathrm{McGarr}^{34)}$ は、地殼内地震の震源近傍 の観測最大速度に震源距離と密度をかけた量 $A_{M}$ が(3)式でよく表現 できることを示している。観測最大加速度のサイト増幅特性と $Q$ 值 の影響が小さい場合には、 $\omega^{-2}$ モデルに基づく短周期レベルと $A_{M}$ は 線形関係になるという解釈が可能である。ここで示した本研究の考 え方には、海溝型地震の発生に関与寸ると考えられる温度や摩擦係 数の違いや、流体の影響などが考慮されていないが、以上のような 
観点に基づき、 $\log _{10} Y$ が $\log _{10} D$ と線形関係にある距離減衰式とした。

(1)式の $c_{J}$ はサイト係数であり、全観測点のサイト係数の平均值を $c_{0}$ と表し、 $V s 400 \sim 600 \mathrm{~m} / \mathrm{s}$ の基盤、Vs600 $800 \mathrm{~m} / \mathrm{s}$ の基盤、 $V s 800 \sim$ $1000 \mathrm{~m} / \mathrm{s}$ の基盤、 $V s 3000 \mathrm{~m} / \mathrm{s}$ 程度の地震基盤、道路橋示方書 ${ }^{35)}$ の定義 に基づく I 種地盤、II 種地盤、III 種地盤の観測点のサイト係数の平 均值をそれぞれ、 $c_{500} 、 c_{700} 、 c_{900} 、 c_{3000} 、 c_{\text {I }} 、 c_{\text {III }} 、 c_{\text {III }}$ と表す。 $V_{s} 400 \sim$ $600 \mathrm{~m} / \mathrm{s} 、 V s 600 \sim 800 \mathrm{~m} / \mathrm{s} 、 V s 800 \sim 1000 \mathrm{~m} / \mathrm{s}$ の基盤の観測点は、PS 検 層データにこの範囲の $V S$ の層があり、その最上面から地表までの地 盤の特性值=卓越周期(告示スペクトルおよび道路橋示方書 ${ }^{35}$ )の定 義による)が 0.05 秒以下となる観測点とした。 $c_{700}$ は、片岡・他 ${ }^{36)}$ 、 佐藤 7)で定義した工学的基盤と同じ定義である。なお、同じ定義で $V s$ が $1000 \mathrm{~m} / \mathrm{s}$ 以上となる観測点はほとんどなかったため、V $1000 \mathrm{~m} / \mathrm{s}$ 以上に対するサイト係数は求められなかった。

回帰分析手法は、二段階回帰分析手法であり、一段階目はスペク トルインバージョン手法例えば 10),11),15),36) と同じである7)。地盤の非線 形性がある場合には、同じ観測点でもサイト係数が異なる可能性が ある。そこで、全継続時間の 3 成分のいずれかの最大加速度が 200 $\sim 400 \mathrm{~cm} / \mathrm{s}^{2} 、 400 \mathrm{~cm} / \mathrm{s}^{2}$ 以上の場合は、上下成分に対する水平成分の スペクトル比 $\mathrm{H} / \mathrm{V}$ を計算する。そして、最大加速度が $200 \mathrm{~cm} / \mathrm{s}^{2}$ 以下 の同一観測点の $\mathrm{H} / \mathrm{V}$ に比ベ、ピークの周期が明らかに長周期化して いる記録は地盤の非線形性の影響があると判断して、同一観測点で も異なる観測点として計算を行なう。そして、二段階目の各観測点 のサイト係数を $c_{700} 、 c_{\text {I }} 、 c_{\text {II }} 、 c_{\text {III }} 、 c_{0}$ に置き換えたときの $e$ が最小と なるように回帰係数を求める ${ }^{7)}$ 。

(2) 地盤同定手法と $c_{3000}$ の算出手法

$V s 3000 \mathrm{~m} / \mathrm{s}$ 程度の地震基盤でのサイト係数 $c_{3000}$ を算出するため、 地震基盤での露頭波(はぎとり波)を求める必要がある。そこで、こ こでは、はぎとりをするために用いる地盤定数を同定する手法につ いて記述する。はじめに、図 1、図 2 に示した $V s 3000 \mathrm{~m} / \mathrm{s}$ 以上の岩 盤がある KiK-net 観測点(東日本で 4 地点、西日本で 7 地点)で観測さ れた $\mathrm{S}$ 波部の地中に対する地表のスペクトル比を 3 成分それぞれに 対して算出する。そして、Transverse 成分と Radial 成分に対しては $\mathrm{S}$ 波の鉛直下方入射、Vertical 成分に対してはP 波の鉛直下方入射を仮 定して ${ }^{37) 、 1}$ 次元理論スペクトル比と観測スペクトル比が合うよう に、弾性波速度と周波数依存減衰定数を同定する。地震基盤では斜 め入射を考慮する方がよいと考えられるが、SV 波の斜め入射を考 慮した既往の研究 $\left.{ }^{39}\right)$ では、P 波の減衰定数 $h p$ の推定には課題がある ことが述べられている。また、この研究 ${ }^{39)}$ で求められている斜め入 射を考慮した場合としない場合の $\mathrm{S}$ 波の減衰定数 $h s$ 差は大きくな い。そこで、本研究では鉛直下方入射を仮定した。同定手法は、焼 きなまし法 ${ }^{38)}$ に基づく方法 ${ }^{39}$ である。hs は $\mathrm{Satoh}^{39)}$ と同様にVs に依 存した(4)式とした。

$$
h s=h_{0 s} f^{-\alpha_{s}}=10^{\beta_{s}} / V_{s} f^{-\alpha_{s}}
$$

$\mathrm{Satoh}^{39)}$ では、P 波入射の場合の同定がなされていないため、P 波の 減衰定数 $h p$ も(4)式の $\mathrm{S}$ 波を意味する添え字 $s$ を $\mathrm{P}$ 波を意味する $p$ に置き換えた式で表現することとした。層厚は PS 検層結果とし、 密度は Gardner et al. ${ }^{40)}$ の式で PS 検層の $\mathrm{P}$ 波速度 $V p$ から算出した值 とした。V $V 、 V s$ はP 検層結果の層区分毎に独立なパラメータとし、 $\alpha_{p} 、 \alpha_{s}$ は全層同じとして同定する。 $\beta_{p} 、 \beta_{s}$ は、はじめに全層同じと して解析を行い、軟弱層で $h p$ や $h s$ が非常に大きくなり理論スペク
トル比と観測スペクトル比のフィッティングが悪い場合は、軟弱層 とそれ以外の層のそれぞれに対して $\beta_{p} 、 \beta_{s}$ を同定した。探索範囲は、 $V p 、 V s$ は PS 検層結果の 0.6 倍〜 1.4 倍とした。ただし、Vs が $500 \mathrm{~m} / \mathrm{s}$ 以下の場合は $0.4 \sim 1.6$ 倍に広げた。 $\alpha_{p} 、 \alpha_{s}$ の探索範囲は $0 \sim 2 、 \beta_{p}$ 、 $\beta_{s}$ の探索範囲は、0 4 である ${ }^{39)}$ 。フィッティングの範囲は、 1 次の ピークが十分にはいる低周波数 $(0.2 \sim 1 \mathrm{~Hz})$ から $15 \mathrm{~Hz}$ までである。は じめに、Transverse 成分と Radial 成分を用いて $V_{s}$ と $h s$ の同定を行 い、次に、Vertical 成分を用いて $V p$ と $h p$ の同定を行う。 $V p$ には、 $V p / V_{s}>2^{0.5}$ の条件をつけた。最小にする残差の定義は $\mathrm{Satoh}^{39)}$ と同じ であり、S 波入斜の場合は、Transverse 成分と Radial 成分のスペク トル比の残差の和を用いる。3つの異なる乱数を用いて同定を行い、 残差が最少の場合の同定值を最適值とした。

水平成分は $\mathrm{S}$ 波速度構造、上下成分は $\mathrm{P}$ 波速度構造を用いて、 $\mathrm{S}$ 波部、全継続時間の地表の観測波形からはぎとり波を求める。次に、 はぎとり波の加速度応答スペクトル、最大加速度、最大速度を求め、 地表での観測波のそれらの比の平均值を算出する。そして、この比 で、地表での観測点固有のサイト係数を補正し、地震基盤でのサイ 卜係数を求める。最後に、各観測点の地震基盤でのサイト係数を平 均し、これを $c_{3000}$ とする。

\section{4. 検討結果}

(1) 地盤同定結果

図 4 には、2004 年 9 月 4 日 19 時の紀伊半島南東沖地震の $\mathrm{AICH} 04$ (安城)での地中 $1055 \mathrm{~m}$ に対寸る地表の観測スペクトル比と フィッティングされた理論スペクトル比を示す。AICH04 では、2 つの地震の記録がデータセットに含まれているため、地盤定数は 2 つの地震の観測スペクトル比にフィッティングするように推定され ている。理論スペクトルは観測スペクトル比を良好に再現している。 なお、観測、理論スペクトル比とも $0.3 \mathrm{~Hz}$ の Partzen Window で平滑 化されている ${ }^{39)}$ 。理論スペクトル比は、地中の観測スペクトルを平 滑化したスペクトルと地表の理論スペクトルを平滑化したスペクト ルの比であるため ${ }^{39)}$ 、水平 2 成分でも若干の差がある。

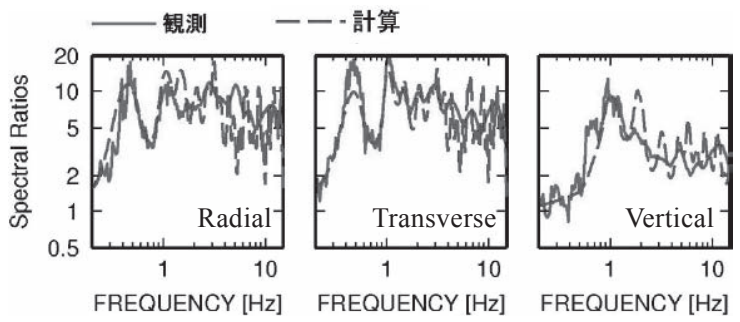

図 4 AICH04での地中に対する地表の観測スペクトル比とフ イッティングされた理論スペクトル比の比較

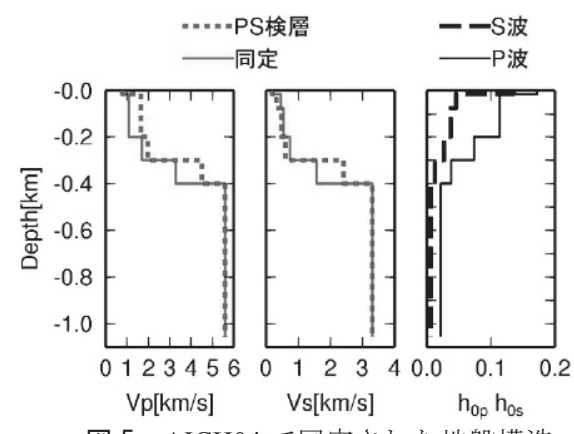

図 5 AICH04 で同定された地盤構造 
図 5 には、同定された地盤定数及び PS 検層結果を示す。同定さ れた $V p 、 V s$ とも、深さ約 $300 \sim 400 \mathrm{~m}$ で PS 検層結果よりかなり小さ いが、この近傍で実施されているアレー微動探査に基づき推定され た $\mathrm{S}$ 波速度構造 ${ }^{41)}$ とよく合っている。減衰定数 $h_{0 p} 、 h_{0 s}$ は、それぞ れ、Vp、Vs に反比例するため深いほど小さく、 $h_{0 p}>h_{0 s}$ の関係があ る。同定された $\alpha_{p} 、 \alpha_{s}$ は、それぞれ、 $0.33 、 0.61$ である。したがっ て、全対象周波数 $0.2 \sim 10 \mathrm{~Hz}$ で $h p>h s$ となり、この関係は藤堂・他 37) と同じである。

(2) 回帰分析結果

表 3、表 4 には、太平洋プレートとフィリピン海プレートの海溝 型地震の最大加速度、最大速度の回帰係数を示す。 $\mathrm{P}$ 波部について は、水平動のはぎとりが困難であるのと、後述のように振幅レベル が小さいため、回帰誤差 $e$ の算定に用いない $c_{3000 、} c_{500 、} c_{900}$ は算出 していない。太平洋プレートの海溝型地震のデータセットには、 $c_{900}$ が算出できる観測点がなかった。なお、 $\mathrm{S}$ 波部の回帰係数は全継続 時間とほぼ同じであったため、ページ数の制約上割愛する。

応答スペクトルの回帰係数は、全継続時間に対する結果を用いて 考察する。太平洋プレートの海溝型地震の全継続時間の応答スペク トルに対する全ての回帰係数を表 5 に、主な回帰係数を図 6 に示す。 フィリピン海プレートの海溝型地震に対する同様の結果を表 6、図 7 に示す。図中には、最大加速度に対する回帰係数を固有周期 0.05 秒 のポイントに示している。両プレートとも、 $a$ は約 $0.2 \sim 1.0$ 秒の短 周期領域で約 0.5 、長周期領域で徐々に 0.5 より大きくなっており、 福島・田中 $\left.{ }^{42}\right)$ で指摘されているように、 $\omega^{-2}$ モデルにより解釈できる。 0.2 秒以下では $f_{\max }$ の影響もあるため、必ずしもこの解䣋が成り立た ないものと考えられる。 $b$ については、長周期領域で、フィリピン 海プレートの方が太平洋プレートより大きい。この原因として、フ イリピン海プレートのデータセットに浅い地震が多いことや、紀伊 半島南東沖の地震は付加体の影響で長周期地震動が卓越すること ${ }^{43}$ が考えられる。回帰誤差 $e$ は、周期 0.1 秒以下の短周期領域を除き 3 成分の中で Vertical 成分が最も小さい。これは、周期 0.1 秒以下の短 周期領域を除き、Vertical 成分は水平成分より地盤の増幅率が小さく、
同じ地盤分類の観測点の増幅率のばらつきが小さくなっているため と考えられる。逆に、周期 0.1 秒以下の短周期領域では、Vertical 成 分の方が増幅率のばらつきが大きい。地盤分類をしたサイト係数を 用いた場合の回帰誤差 $e$ は 0.23〜0.34 であるのに対して、各観測点 固有のサイト係数を用いた場合の回帰残差 error は $0.15 \sim 0.24$ と小 さい。したがって、地震動強さを予測する際に、各観測点固有のサ イト係数を用いれば、ばらつきの小さい予測が可能となる。

以下では、震源深さ依存性を表わ寸回帰係数 $h_{s u b 、} h_{\text {sla }}$ について考 察する。同じプレートの $h_{s u b}$ と $h_{s l a}$ は類似の特徵をもっている。大局 的には、震源深さが深いほど短周期の地震動が大きくなる。 $h_{s u b 、}, h_{s l a}$ は、短周期領域では $2 / 3$ に近く、短周期レベルが $D^{2 / 3}$ に比例すると いう前述の解釈と整合する。短周期領域に比べて長周期領域で $h_{\text {sub }}$ 、 $h_{s l a}$ が小さくなるのは、深くなると表面波の励起が小さくなるためと 考えられる。図 8 には、 $D=30 \mathrm{~km}$ の場合のプレート境界地震に対す るスラブ内地震の応答スペクトルの比を示す。短周期領域では 3 成 分とも、どちらのプレートでも、スラブ内地震の方がプレート境界 地震より約 1.5 倍大きい。長周期領域では、フィリピン海プレート の地震では、ほぼ 1 であり、スラブ内地震とプレート境界地震の違 いがない。これは、上述のように表面波の影響と考えられる。震源 深さもパラメータとなっている水平動に対する司・翠川 ${ }^{18)}$ の式では、 プレート境界地震に対するスラブ内地震の比は、最大加速度で 1.6 倍、最大速度で 1.4 倍である。本研究では、震源梁さ $30 \mathrm{~km}$ で、太 平洋プレートでは 3 成分とも最大加速度、最大速度とも 1.5 倍程度、 フィリピン海プレートでは最大加速度で 1.4 倍程度、最大速度で 1.1 倍程度である。司・翠川 ${ }^{18)}$ の式は日本全国の地震を対象としており、 フィリピン海プレートのスラブ内地震が含まれていなことを考慮す ると、プレート境界地震に対するスラブ内地震の比は本研究と司・ 翠川 ${ }^{18)}$ の式でほぼ整合しているといえる。

本研究の回帰分析で用いた太平洋プレートのスラブ内地震の震源 深さの平均值は $82.8 \mathrm{~km}$ 、プレート境界地震では $37.3 \mathrm{~km}$ である。こ の平均值を用いた場合のプレート境界地震に対するスラブ内地震の 比は、最大加速度の水平成分で 2.9 倍、Vertical 成分で 2.8 倍となる。

表 3 太平洋プレートの海溝型地震の最大加速度と最大速度の回帰係数

\begin{tabular}{|c|c|c|c|c|c|c|c|c|c|c|c|c|c|c|}
\hline 最大加速度 & $a$ & $h_{\text {sub }}$ & $h_{\text {sla }}$ & $b$ & $d$ & $c_{0}$ & $c_{700}$ & $c_{\mathrm{I}}$ & $c_{\mathrm{II}}$ & $c_{\text {III }}$ & $c_{3000}$ & $c_{500}$ & $e$ & error \\
\hline P波部:Radial & 0.531 & 0.417 & 0.572 & -0.00307 & 0.0140 & -0.657 & -0.787 & -0.628 & -0.602 & -0.749 & - & - & 0.318 & 0.210 \\
\hline P波部:Transverse & 0.528 & 0.418 & 0.581 & -0.00319 & 0.0145 & -0.659 & -0.804 & -0.627 & -0.608 & -0.729 & - & - & 0.327 & 0.210 \\
\hline P波部:Vertical & 0.467 & 0.547 & 0.703 & -0.00451 & 0.0080 & -0.306 & -0.433 & -0.299 & -0.250 & -0.328 & - & - & 0.324 & 0.222 \\
\hline 全継続時間:Radial & 0.522 & 0.690 & 0.808 & -0.00305 & 0.0055 & -0.452 & -0.538 & -0.465 & -0.412 & -0.424 & -1.036 & -0.620 & 0.307 & 0.217 \\
\hline 全継続時間:Transverse & 0.509 & 0.685 & 0.802 & -0.00311 & 0.0055 & -0.342 & -0.421 & -0.356 & -0.298 & -0.313 & -0.904 & -0.538 & 0.310 & 0.219 \\
\hline 全継続時間:Vertical & 0.472 & 0.493 & 0.639 & -0.00321 & 0.0025 & -0.152 & -0.204 & -0.153 & -0.123 & -0.173 & -0.599 & -0.252 & 0.302 & 0.209 \\
\hline 最大速度 & $a$ & $h_{\text {sub }}$ & $h_{\text {sla }}$ & $b$ & $d$ & $c_{0}$ & $c_{700}$ & $c_{\mathrm{I}}$ & $c_{\mathrm{II}}$ & $c_{I I I}$ & $c_{3000}$ & $c_{500}$ & $e$ & error \\
\hline 皮部:Radial & 0.480 & 0.417 & 0.570 & -0.00277 & 0.0085 & -0.394 & -0.523 & -0.364 & -0.340 & -0.486 & - & - & 0.320 & 0.211 \\
\hline 波部:Transverse & 0.474 & 0.299 & 0.416 & -0.00262 & 0.0065 & -1.599 & -1.842 & -1.608 & -1.520 & -1.508 & - & - & 0.344 & 0.239 \\
\hline P波部:Vertical & 0.414 & 0.324 & 0.438 & -0.00349 & 0.0065 & -1.077 & -1.188 & -1.071 & -1.034 & -1.070 & - & - & 0.294 & 0.201 \\
\hline 全継続時間:Radial & 0.499 & 0.459 & 0.586 & -0.00261 & 0.0020 & -1.192 & -1.429 & -1.249 & -1.119 & -1.003 & -1.831 & -1.368 & 0.289 & 0.201 \\
\hline 全継続時間:Transverse & 0.481 & 0.553 & 0.651 & -0.00252 & 0.0020 & -1.208 & -1.427 & -1.274 & -1.123 & -1.019 & -1.861 & -1.454 & 0.294 & 0.208 \\
\hline 全継続時間:Vertical & 0.474 & 0.194 & 0.307 & -0.00198 & 0.0025 & -1.018 & -1.148 & -1.026 & -0.988 & -0.970 & -1.387 & -1.040 & 0.260 & 0.175 \\
\hline
\end{tabular}

表 4 フィリピン海プレートの海溝型地震の最大加速度と最大速度の回帰係数

\begin{tabular}{|c|c|c|c|c|c|c|c|c|c|c|c|c|c|c|c|}
\hline 最大加速度 & a & $h_{\text {sub }}$ & $h_{\text {sla }}$ & $b$ & $d$ & $c_{0}$ & $c_{700}$ & $c_{\mathrm{I}}$ & $c_{\mathrm{II}}$ & $c_{\mathrm{III}}$ & $c_{3000}$ & $c_{500}$ & $c_{900}$ & $e$ & error \\
\hline P波部：Radial & 0.606 & 1.377 & 1.493 & -0.003461 & 0.0140 & -2.724 & -3.016 & -2.729 & -2.662 & -2.633 & - & - & - & 0.385 & 0.267 \\
\hline P波部：Transverse & 0.632 & 1.479 & 1.603 & -0.003539 & 0.0145 & -3.094 & -3.433 & -3.097 & -3.032 & -2.995 & - & - & - & 0.390 & 0.265 \\
\hline P波部:Vertical & 0.594 & 1.389 & 1.536 & -0.004479 & 0.0080 & -2.638 & -2.828 & -2.663 & -2.536 & -2.509 & - & - & - & 0.380 & 0.280 \\
\hline 全継続時間:Radial & 0.518 & 0.496 & 0.596 & -0.003614 & 0.0055 & -0.220 & -0.556 & -0.224 & -0.162 & -0.079 & -0.935 & -0.371 & -0.543 & 0.287 & 0.154 \\
\hline 全継続時間:Transverse & 0.522 & 0.524 & 0.612 & -0.003807 & 0.0055 & -0.248 & -0.588 & -0.250 & -0.194 & -0.115 & -0.980 & -0.388 & -0.635 & 0.294 & 0.154 \\
\hline 全継続時間:Vertical & 0.532 & 0.454 & 0.565 & -0.003925 & 0.0025 & -0.607 & -0.858 & -0.624 & -0.530 & -0.424 & -0.978 & -0.747 & -0.995 & 0.277 & 0.151 \\
\hline 最大速度 & $a$ & $h_{\text {sub }}$ & $h_{\text {sla }}$ & $b$ & $d$ & $c_{0}$ & $c_{700}$ & $c_{\mathrm{I}}$ & $c_{\text {II }}$ & $c_{\text {III }}$ & $c_{3000}$ & $c_{500}$ & $c_{900}$ & $e$ & error \\
\hline P波部：Radial & 0.612 & 1.378 & 1.443 & -0.00180 & 0.0085 & -4.365 & -4.549 & -4.399 & -4.260 & -4.126 & - & - & - & 0.350 & 0.259 \\
\hline P波部:Transverse & 0.620 & 1.645 & 1.708 & -0.00179 & 0.0065 & -4.948 & -5.215 & -4.983 & -4.824 & -4.691 & - & - & - & 0.381 & 0.267 \\
\hline P波部:Vertical & 0.576 & 1.422 & 1.489 & -0.00251 & 0.0065 & -4.192 & -4.246 & -4.222 & -4.113 & -4.035 & - & - & - & 0.331 & 0.257 \\
\hline 全継続時間:Radial & 0.490 & 0.463 & 0.506 & -0.00242 & 0.0020 & -1.380 & -1.638 & -1.422 & -1.245 & -1.090 & -1.994 & -1.533 & -1.788 & 0.278 & 0.158 \\
\hline 全継続時間:Transverse & 0.486 & 0.488 & 0.512 & -0.00230 & 0.0020 & -1.382 & -1.601 & -1.425 & -1.253 & -1.075 & -2.015 & -1.563 & -1.788 & 0.284 & 0.167 \\
\hline 全継続時間:Vertical & 0.492 & 0.333 & 0.375 & -0.00121 & 0.0025 & -1.656 & -1.780 & -1.679 & -1.592 & -1.479 & -2.016 & -1.699 & -1.925 & 0.238 & 0.149 \\
\hline
\end{tabular}


表 5 太平洋プレートの海溝型地震の加速度応答スペクトルの回帰係数 (上段:Radial、中段:Transverse、下段:Vertical)

\begin{tabular}{|c|c|c|c|c|c|c|c|c|c|c|c|c|c|c|}
\hline$T$ & $a$ & $h_{\text {sub }}$ & $h_{s l g}$ & $b$ & $d$ & $c_{0}$ & $c_{700}$ & $c_{\mathrm{I}}$ & $c_{\mathrm{II}}$ & $c_{\mathrm{III}}$ & $c_{3000}$ & $c_{500}$ & $e$ & error \\
\hline 0.07 & 0.569 & 0.801 & 0.929 & -0.00346 & 0.0085 & -0.693 & -0.593 & -0.660 & -0.711 & -0.757 & -1.194 & -0.739 & 0.327 & 0.221 \\
\hline 0.10 & 0.596 & 0.790 & 0.919 & -0.00359 & 0.0110 & -0.704 & -0.688 & -0.668 & -0.712 & -0.769 & -1.306 & -0.801 & 0.343 & 0.233 \\
\hline 0.15 & 0.555 & 0.688 & 0.807 & -0.00348 & \begin{tabular}{|l|l|l|}
0.0070 \\
\end{tabular} & -0.229 & -0.370 & $\begin{array}{r}0.000 \\
-0.228\end{array}$ & -0.180 & -0.257 & \begin{tabular}{|l|}
1.000 \\
-0.844
\end{tabular} & -0.390 & 0.341 & 0.226 \\
\hline 0.20 & 0.512 & 0.614 & 0.727 & -0.00308 & 0.0050 & 0.121 & -0.097 & 0.092 & 0.213 & 0.129 & -0.455 & -0.048 & 0.339 & 0.220 \\
\hline 0.25 & 0.516 & 0.014 & 0.677 & $\frac{.00000}{-0.00274}$ & 0.0040 & 0.083 & $\frac{.031}{-0.172}$ & 0.035 & 0.191 & 0.126 & $\begin{array}{r}0.400 \\
-0.531\end{array}$ & $\frac{.040}{-0.096}$ & 0.336 & 0.221 \\
\hline 0.30 & 0.503 & 0.477 & 0.604 & -0.00263 & 0.0035 & 0.248 & -0.011 & 0.188 & 0.368 & 0.312 & -0.407 & 0.082 & 0.337 & 0.221 \\
\hline 0.40 & 0.492 & 0.588 & 0.698 & -0.00186 & $\begin{array}{l}0.0025 \\
0.0025\end{array}$ & -0.053 & -0.339 & -0.134 & 0.085 & 0.070 & $\begin{array}{l}0.771 \\
-0.70\end{array}$ & -0.174 & 0.332 & 0.221 \\
\hline 0.50 & 0.487 & 0.524 & 0.634 & -0.00157 & 0.0025 & -0.042 & -0.336 & -0.136 & 0.091 & 0.162 & -0.713 & -0.144 & 0.326 & 0.212 \\
\hline 0.60 & 0.463 & 0.441 & 0.544 & -0.00180 & \begin{tabular}{|l|}
0.0020 \\
\end{tabular} & 0.209 & -0.069 & 0.116 & 0.330 & 0.442 & -0.531 & 0.103 & 0.325 & 0.207 \\
\hline 0.70 & 0.471 & 0.414 & 0.516 & -0.00174 & 0.0020 & 0.111 & -0.183 & 0.020 & 0.219 & 0.382 & -0.605 & 0.002 & 0.330 & 0.204 \\
\hline 0.80 & 0.473 & 0.316 & 0.431 & -0.00171 & 0.0020 & 0.194 & -0.109 & 0.104 & 0.293 & 0.491 & -0.555 & 0.090 & 0.334 & 0.203 \\
\hline 0.90 & 0.475 & 0.325 & 0.444 & -0.00160 & 0.0015 & 0.080 & -0.207 & -0.009 & 0.164 & 0.411 & -0.659 & -0.007 & 0.339 & 0.200 \\
\hline 1.00 & 0.483 & 0.314 & 0.435 & -0.00204 & 0.0015 & 0.039 & -0.218 & -0.046 & 0.112 & 0.374 & \begin{tabular}{|l}
-0.714 \\
\end{tabular} & -0.029 & 0.342 & 0.200 \\
\hline 1.50 & 0.500 & 0.273 & 0.396 & -0.00229 & 0.0020 & -0.195 & -0.474 & -0.263 & -0.139 & 0.112 & -0.986 & -0.266 & 0.358 & 0.207 \\
\hline 2.00 & 0.535 & 0.325 & 0.438 & -0.00258 & 0.0020 & -0.666 & -0.979 & -0.735 & -0.605 & -0.372 & $\begin{array}{l}-1.355 \\
\end{array}$ & -0.760 & 0.368 & 0.208 \\
\hline 2.50 & 0.553 & 0.293 & 0.401 & -0.00279 & 0.0015 & -0.855 & -1.159 & -0.927 & -0.787 & -0.601 & $\begin{array}{r}1.062 \\
-1.462\end{array}$ & -0.963 & 0.365 & 0.207 \\
\hline 3.00 & 0.595 & 0.274 & 0.377 & -0.00282 & 0.0025 & -1.211 & -1.501 & -1.274 & -1.142 & -0.989 & -1.810 & -1.291 & 0.360 & 0.204 \\
\hline 4.00 & 0.569 & 0.114 & 0.207 & -0.00248 & 0.0030 & -0.997 & -1.220 & -1.058 & -0.925 & -0.782 & -1.635 & -1.080 & 0.349 & 0.192 \\
\hline 5.00 & 0.613 & 0.028 & 0.134 & -0.00203 & 0.0030 & -1.417 & -1.626 & -1.474 & -1.339 & -1.205 & -1.982 & -1.503 & 0.331 & 0.179 \\
\hline$T$ & $a$ & $h_{\text {sub }}$ & $h_{s I_{a}}$ & $b$ & $d$ & $c_{0}$ & $c_{700}$ & $c_{\mathrm{I}}$ & $c_{I I}$ & $c_{\text {III }}$ & $c_{3000}$ & $c_{500}$ & $e$ & error \\
\hline 0.07 & 0.560 & 0.754 & 0.888 & -0.00348 & 0.0090 & -0.547 & -0.480 & -0.511 & -0.565 & -0.615 & -1.017 & -0.592 & 0.329 & 0.220 \\
\hline 0.10 & 0.565 & 0.751 & 0.876 & -0.00365 & 0.0095 & -0.426 & -0.395 & -0.393 & -0.431 & -0.486 & -1.008 & -0.551 & 0.343 & 0.223 \\
\hline 0.15 & 0.534 & 0.706 & 0.822 & -0.00372 & 0.0070 & -0.067 & -0.179 & -0.063 & -0.021 & -0.101 & -0.650 & -0.252 & 0.350 & 0.229 \\
\hline 0.20 & 0.521 & 0.631 & 0.734 & -0.00334 & 0.0050 & 0.074 & -0.111 & 0.055 & 0.147 & 0.078 & -0.452 & -0.108 & 0.346 & 0.226 \\
\hline 0.25 & 0.503 & 0.537 & 0.657 & -0.00288 & 0.0035 & 0.239 & 0.011 & 0.199 & 0.341 & 0.267 & -0.367 & 0.050 & 0.339 & 0.217 \\
\hline 0.30 & 0.502 & 0.500 & 0.611 & -0.00249 & 0.0035 & 0.211 & -0.009 & 0.155 & 0.319 & 0.287 & -0.438 & 0.043 & 0.336 & 0.219 \\
\hline 0.40 & 0.488 & 0.515 & 0.629 & -0.00194 & 0.0020 & 0.098 & -0.140 & 0.014 & 0.237 & 0.224 & -0.645 & -0.049 & 0.324 & 0.218 \\
\hline 0.50 & 0.479 & 0.508 & 0.606 & -0.00211 & 0.0025 & 0.120 & -0.137 & 0.021 & 0.258 & 0.316 & -0.567 & -0.032 & 0.322 & 0.215 \\
\hline 0.60 & 0.468 & 0.458 & 0.557 & -0.00210 & 0.0020 & 0.196 & -0.032 & 0.099 & 0.329 & 0.406 & -0.579 & 0.054 & 0.323 & 0.209 \\
\hline 0.70 & 0.477 & 0.489 & 0.580 & -0.00179 & \begin{tabular}{|l|}
0.0020 \\
\end{tabular} & -0.030 & -0.288 & -0.130 & 0.090 & 0.223 & -0.861 & -0.212 & 0.329 & 0.206 \\
\hline 0.80 & 0.493 & 0.487 & 0.582 & -0.00116 & 0.0020 & -0.289 & -0.534 & -0.387 & -0.178 & -0.003 & -1.053 & -0.457 & 0.329 & 0.207 \\
\hline 0.90 & 0.465 & 0.440 & 0.531 & -0.00119 & 0.0015 & -0.072 & -0.310 & -0.170 & 0.022 & 0.243 & \begin{tabular}{|l|}
-0.851 \\
\end{tabular} & -0.235 & 0.337 & 0.212 \\
\hline 1.00 & 0.468 & 0.444 & 0.532 & -0.00112 & 0.0020 & -0.147 & -0.337 & -0.240 & -0.064 & 0.173 & -0.914 & -0.305 & 0.338 & 0.213 \\
\hline 1.50 & 0.470 & 0.413 & 0.494 & -0.00180 & 0.0015 & -0.248 & -0.436 & -0.328 & -0.177 & 0.053 & -1.023 & -0.362 & 0.345 & 0.213 \\
\hline 2.00 & 0.484 & 0.553 & 0.617 & -0.00169 & 0.0015 & -0.753 & -0.945 & -0.835 & -0.686 & -0.486 & -1.528 & -0.853 & 0.358 & 0.217 \\
\hline 2.50 & 0.490 & 0.496 & 0.553 & -0.00222 & 0.0010 & -0.782 & -1.004 & -0.858 & -0.713 & -0.534 & -1.576 & -0.893 & 0.350 & 0.210 \\
\hline 3.00 & 0.479 & 0.378 & 0.436 & -0.00247 & 0.0010 & -0.590 & -0.830 & -0.655 & -0.515 & -0.388 & \begin{tabular}{|l|}
-1.363 \\
\end{tabular} & -0.676 & 0.355 & 0.213 \\
\hline 4.00 & 0.498 & 0.200 & 0.272 & -0.00275 & 0.0015 & -0.589 & -0.799 & -0.657 & -0.510 & -0.403 & -1.339 & -0.691 & 0.340 & 0.203 \\
\hline 5.00 & 0.569 & 0.087 & 0.181 & -0.00279 & 0.0015 & -1.094 & -1.281 & -1.157 & -1.016 & -0.902 & -1.810 & -1.179 & 0.324 & 0.194 \\
\hline$T$ & $a$ & $h_{\text {sub }}$ & $h_{\text {sla }}$ & $b$ & $d$ & $c_{0}$ & $c_{700}$ & $c_{\mathrm{I}}$ & $c_{I I}$ & $c_{\text {III }}$ & $c_{3000}$ & $c_{500}$ & $e$ & error \\
\hline 0.07 & 0.516 & 0.624 & 0.800 & -0.00432 & 0.0025 & -0.216 & -0.264 & -0.188 & -0.200 & -0.273 & -0.677 & -0.262 & 0.358 & 0.237 \\
\hline 0.10 & 0.497 & 0.611 & 0.761 & -0.00393 & 0.0025 & -0.060 & -0.122 & -0.056 & -0.013 & -0.117 & -0.396 & -0.172 & 0.349 & 0.226 \\
\hline 0.15 & 0.472 & 0.488 & 0.628 & -0.00318 & 0.0020 & 0.198 & 0.079 & 0.175 & 0.274 & 0.178 & -0.262 & 0.077 & 0.321 & 0.212 \\
\hline 0.20 & 0.484 & 0.496 & 0.606 & -0.00280 & 0.0035 & 0.040 & -0.057 & 0.009 & 0.106 & 0.052 & -0.386 & -0.050 & 0.304 & 0.203 \\
\hline 0.25 & 0.483 & 0.424 & 0.534 & -0.00236 & 0.0035 & 0.062 & -0.023 & 0.030 & 0.125 & 0.074 & -0.370 & -0.068 & 0.290 & 0.197 \\
\hline 0.30 & 0.483 & & 0.557 & -0.00196 & 0.0040 & -0.080 & -0.177 & -0.111 & -0.036 & -0.025 & -0.500 & -0.188 & 0.276 & 0.192 \\
\hline 0.40 & 0.509 & 0.458 & 0.564 & -0.00113 & 0.0040 & -0.451 & -0.540 & -0.484 & -0.409 & -0.376 & -0.943 & -0.547 & 0.272 & 0.182 \\
\hline 0.50 & & & & -0.00131 & & & & & -0.348 & & -0.781 & & 0.268 & \\
\hline 0.60 & 0.484 & 0.329 & 0.412 & -0.00141 & 0.0045 & -0.148 & -0.243 & -0.177 & -0.114 & -0.060 & -0.682 & -0.222 & 0.270 & 0.174 \\
\hline 0.70 & & & & & & & & & & -0.107 & & & & 0.172 \\
\hline 0.80 & 0.474 & 0.215 & 0.313 & -0.00083 & 0.0040 & -0.088 & -0.210 & -0.104 & -0.065 & -0.007 & -0.685 & -0.133 & 0.281 & 0.173 \\
\hline 0.90 & & & 0.277 & -0.00086 & & -0.055 & -0.179 & -0.070 & -0.037 & 0.027 & -0.662 & -0.093 & 0.282 & \\
\hline 1.00 & 0.461 & 0.171 & 0.253 & -0.00101 & 0.0030 & 0.003 & -0.124 & -0.008 & 0.021 & 0.076 & -0.598 & -0.022 & 0.287 & 0.174 \\
\hline 1.50 & 0.466 & 0.043 & 0.144 & -0.00128 & 0.0025 & -0.006 & -0.155 & -0.019 & 0.028 & 0.083 & -0.540 & 0.012 & 0.312 & 0.186 \\
\hline 2.00 & 0.499 & 0.171 & 0.259 & -0.00117 & 0.0020 & -0.629 & -0.743 & -0.654 & -0.578 & -0.529 & -1.074 & -0.599 & 0.322 & 0.186 \\
\hline 2.50 & 0.546 & 0.061 & 0.152 & -0.00152 & 0.0020 & -0.848 & -1.046 & -0.877 & -0.787 & -0.765 & -1.200 & -0.8 & 0.329 & 0.192 \\
\hline 3.00 & 0.545 & -0.053 & 0.026 & -0.00174 & 0.0020 & -0.713 & -0.927 & -0.739 & -0.655 & -0.639 & -1.045 & -0.716 & 0.324 & 0.200 \\
\hline 4.00 & 0.560 & -0.167 & -0.092 & -0.00173 & 0.0025 & -0.807 & -1.002 & -0.825 & -0.762 & -0.730 & -1.186 & -0.798 & 0.316 & 0.198 \\
\hline 5.00 & 0.648 & -0.278 & -0.191 & -0.00161 & 0.0040 & -1.406 & -1.592 & -1.419 & -1.374 & -1.315 & -1.762 & -1.368 & 0.291 & 0.180 \\
\hline
\end{tabular}

$\triangle \quad--\cdot$ Radial

$\nabla \quad$ m.n." Transverse

O Vertical
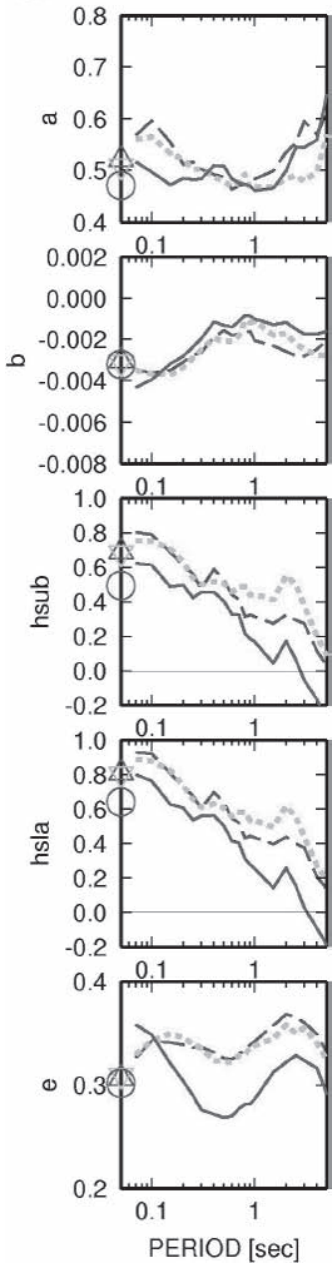

図 6 太平洋プレートの海溝 型地震の加速度応答スペクト ルと最大加速度の回帰係数
フィリピン海プレートのスラブ内地震の震源深さの平均值は $40.3 \mathrm{~km}$ 、プレート境界地震では $35.3 \mathrm{~km}$ である。この平均值を用い た場合のプレート境界地震に対するスラブ内地震の比は、最大加速 度の水平成分で 1.5 倍、Vertical 成分で 1.6 倍程度である。応答スペ クトルの短周期領域でもほぼ同様の倍率である。佐藤 ${ }^{44)}$ は、宮城県 沖と福島県沖では、スラブ内地震の短周期レベルがプレート境界地 震より平均的に 2.7 倍大きいことを指摘しており、本研究の太平洋 プレートに対する式とほぼ整合している。震源深さをパラメータと していないKanno et al. ${ }^{45}$ の水平動の距離減衰式に森川・他 ${ }^{46)}$ の東日 本の異常震域を考慮した場合、太平洋プレートのプレート境界地震 に対するスラブ内地震の比は、最大加速度で 2.1 倍、最大速度で 2.4 倍である。本研究の比の方が大きい原因として、森川・他 ${ }^{46)}$ では K-NET と KiK-net 観測点の記録のみを用いているため、1996 年以前 に発生した北海道東方沖地震や釧路沖地震などの短周期レベルが大 きい13),36)スラブ内地震が含まれていなことが考えられる。

図 9 には、地震基盤に対するサイト増幅率 $C_{J} / C_{3000}=10^{\left(c_{J}-c_{3000}\right)}$ を示 す。 $C_{700}$ の水平成分の短周期領域を除くと、基盤の $\mathrm{S}$ 波速度が大き いほど増幅率が小さい。

\section{5. 本研究の距離減衰式の考察}

図 10 には、回帰分析に用いたデータのうち、スラブ内地震である 2003 年宮城県沖地震 $(M w 7.1)$ と 2001 年芸予地震 $(M w 6.9)$ の全継続時 間の観測最大加速度(Radial 成分と Vertical 成分) と、本研究の距離減 衰式の比較を示す。距離減衰式は、全観測点のサイト係数の平均值 $c_{0}$ を用いたものである。観測最大加速度は、回帰分析に用いた火山 フロント前弧側と回帰分析に用いていない背弧側の観測点の両方を 示した。距離減衰式は、火山フロント前弧側の観測点の観測最大加 速度を大局的に説明している。2003 年宮城県沖地震では、水平動の 記録に指摘されている ${ }^{32), 211}$ ように、上下動でも火山フロント前弧側 と背弧側の距離減衰特性に顕著な差があることがわかる。これに対 して、2001 年芸予地震の背弧側の観測点の半数は、火山フロントを 通過していない観測点であるが、火山フロントを通過していると考 えられる観測点でも、火山フロント前弧側と背弧側の距離減衰特性 に差がみられなかった。今回用いた他のフィリピン海プレートの地 震でも同様であった。スラブ内地震の距離減衰特性に火山フロント 直下付近の浅い領域の $Q$ 值が効くことが指摘されているが ${ }^{21)}$ 、中村 14)の三次元 $Q$ 值構造は、深さ $0 \sim 30 \mathrm{~km}$ では、九州では北海道や東北 
表 6 フィリピン海プレートの海溝型地震の加速度応答スペクトルの回帰係数 (上段:Radial、中段:Transverse、下段:Vertical)

\begin{tabular}{|c|c|c|c|c|c|c|c|c|c|c|c|c|c|c|c|}
\hline$T$ & $a$ & $h_{s u b}$ & $h_{s l a}$ & $b$ & $d$ & $c_{0}$ & $c_{700}$ & $c_{\mathrm{I}}$ & $c_{\mathrm{II}}$ & $c_{\text {III }}$ & $c_{3000}$ & $c_{500}$ & $c_{900}$ & $e$ & error \\
\hline 0.07 & 0.564 & 0.558 & 0.691 & -0.00420 & 0.0085 & -0.312 & -0.639 & -0.293 & -0.320 & -0.241 & -0.880 & -0.353 & -0.583 & 0.324 & 0.156 \\
\hline 0.10 & 0.606 & 0.504 & 0.665 & -0.00480 & 0.0110 & -0.354 & -0.706 & -0.332 & -0.364 & -0.297 & -1.053 & -0.425 & -0.668 & 0.330 & 0.157 \\
\hline 0.15 & 0.538 & 0.475 & 0.599 & -0.00375 & 0.0070 & 0.057 & -0.275 & 0.058 & 0.106 & 0.154 & -0.674 & -0.075 & -0.224 & 0.319 & 0.158 \\
\hline 0.20 & 0.515 & 0.396 & 0.505 & -0.00368 & 0.0050 & 0.289 & -0.035 & 0.269 & 0.410 & 0.404 & -0.406 & 0.119 & -0.023 & 0.306 & 0.152 \\
\hline 0.25 & 0.504 & 0.388 & 0.472 & -0.00336 & 0.0040 & 0.315 & 0.030 & 0.281 & 0.460 & 0.483 & -0.474 & 0.156 & 0.009 & 0.312 & 0.150 \\
\hline 0.30 & 0.490 & 0.323 & 0.389 & -0.00331 & 0.0035 & 0.464 & 0.191 & 0.420 & 0.639 & 0.655 & -0.248 & 0.319 & 0.162 & 0.318 & 0.146 \\
\hline 0.40 & 0.469 & 0.373 & 0.375 & -0.00290 & 0.0025 & 0.447 & 0.180 & 0.393 & 0.635 & 0.705 & -0.291 & 0.324 & 0.163 & 0.324 & 0.157 \\
\hline 0.50 & 0.512 & 0.383 & 0.396 & -0.00314 & 0.0025 & 0.057 & -0.193 & -0.007 & 0.246 & 0.447 & -0.743 & -0.099 & -0.240 & 0.338 & 0.160 \\
\hline 0.60 & 0.496 & 0.382 & 0.388 & -0.00249 & 0.0020 & -0.012 & -0.253 & -0.075 & 0.155 & 0.452 & -0.819 & -0.139 & -0.292 & 0.335 & 0.182 \\
\hline 0.70 & 0.518 & 0.434 & 0.434 & -0.00229 & 0.0020 & -0.336 & -0.555 & -0.404 & -0.168 & 0.179 & -1.105 & -0.458 & -0.628 & 0.336 & 0.185 \\
\hline 0.80 & 0.511 & 0.548 & 0.533 & -0.00179 & 0.0020 & -0.581 & -0.800 & -0.647 & -0.417 & -0.090 & -1.304 & -0.705 & -0.841 & 0.335 & 0.188 \\
\hline 0.90 & 0.514 & 0.630 & 0.596 & -0.00152 & 0.0015 & -0.801 & -1.024 & -0.863 & -0.642 & -0.345 & -1.453 & -0.929 & -1.044 & 0.333 & 0.187 \\
\hline 1.00 & 0.531 & 0.634 & 0.612 & -0.00151 & 0.0015 & -0.990 & -1.222 & -1.049 & -0.834 & -0.564 & -1.622 & -1.112 & -1.211 & 0.331 & 0.183 \\
\hline 1.50 & 0.553 & 0.541 & 0.527 & -0.00110 & 0.0020 & -1.330 & -1.486 & -1.385 & -1.168 & -1.059 & -2.071 & -1.447 & -1.514 & 0.323 & 0.175 \\
\hline 2.00 & 0.590 & 0.308 & 0.329 & -0.00104 & 0.0020 & -1.475 & -1.639 & -1.524 & -1.325 & -1.255 & -2.125 & -1.566 & -1.706 & 0.320 & 0.180 \\
\hline 2.50 & 0.632 & 0.352 & 0.371 & -0.00085 & 0.0015 & -2.022 & -2.168 & -2.067 & -1.888 & -1.793 & -2.536 & -2.103 & -2.276 & 0.316 & 0.173 \\
\hline 3.00 & 0.676 & 0.434 & 0.432 & -0.00119 & 0.0025 & -2.513 & -2.637 & -2.557 & -2.389 & -2.277 & -3.025 & -2.596 & -2.770 & 0.316 & 0.168 \\
\hline 4.00 & 0.693 & 0.335 & 0.325 & -0.00128 & 0.0030 & -2.677 & -2.802 & -2.716 & -2.568 & -2.461 & -3.278 & -2.741 & -2.905 & 0.288 & 0.166 \\
\hline 5.00 & 0.721 & 0.309 & 0.303 & -0.00159 & 0.0030 & -2.957 & -3.053 & -2.995 & -2.860 & -2.717 & -3.433 & -3.024 & -3.150 & 0.272 & 0.163 \\
\hline$T$ & $a$ & $h_{\text {sub }}$ & $h_{s l a}$ & $b$ & $d$ & $c_{0}$ & $c_{700}$ & $c_{\mathrm{I}}$ & $c_{\mathrm{II}}$ & $c_{I I I}$ & $c_{3000}$ & $c_{500}$ & $c_{900}$ & $e$ & error \\
\hline 0.07 & 0.578 & 0.542 & 0.669 & -0.00462 & 0.0090 & -0.314 & -0.651 & -0.294 & -0.323 & -0.241 & -0.882 & -0.331 & -0.582 & 0.335 & 0.160 \\
\hline 0.10 & 0.591 & 0.516 & 0.653 & -0.00486 & 0.0095 & -0.246 & -0.620 & -0.223 & -0.258 & -0.186 & -0.914 & -0.311 & -0.566 & 0.333 & 0.155 \\
\hline 0.15 & 0.531 & 0.443 & 0.550 & -0.00400 & 0.0070 & 0.203 & -0.158 & 0.208 & 0.245 & 0.287 & -0.601 & 0.091 & -0.125 & 0.321 & 0.156 \\
\hline 0.20 & 0.519 & 0.435 & 0.537 & -0.00381 & 0.0050 & 0.228 & -0.077 & 0.212 & 0.332 & 0.328 & -0.535 & 0.086 & -0.104 & 0.312 & 0.158 \\
\hline 0.25 & 0.519 & 0.378 & 0.452 & -0.00397 & 0.0035 & 0.309 & -0.008 & 0.278 & 0.450 & 0.468 & -0.454 & 0.171 & 0.022 & 0.311 & 0.154 \\
\hline 0.30 & 0.511 & 0.421 & 0.475 & -0.00374 & 0.0035 & 0.242 & -0.077 & 0.197 & 0.424 & 0.446 & -0.520 & 0.096 & -0.089 & 0.321 & 0.153 \\
\hline 0.40 & 0.467 & 0.376 & 0.399 & -0.00266 & 0.0020 & 0.394 & 0.099 & 0.338 & 0.594 & 0.651 & -0.385 & 0.265 & 0.093 & 0.332 & 0.161 \\
\hline 0.50 & 0.484 & 0.395 & 0.395 & -0.00247 & 0.0025 & 0.153 & -0.116 & 0.094 & 0.331 & 0.528 & -0.636 & -0.001 & -0.162 & 0.334 & 0.170 \\
\hline 0.60 & 0.480 & 0.433 & 0.443 & -0.00180 & 0.0020 & -0.082 & -0.300 & -0.148 & 0.092 & 0.379 & -0.913 & -0.225 & -0.334 & 0.334 & 0.178 \\
\hline 0.70 & 0.498 & 0.529 & 0.545 & -0.00141 & 0.0020 & -0.480 & -0.714 & -0.553 & -0.299 & 0.054 & -1.261 & -0.641 & -0.763 & 0.341 & 0.188 \\
\hline 0.80 & 0.483 & 0.650 & 0.655 & -0.00078 & 0.0020 & -0.702 & -0.946 & -0.771 & -0.527 & -0.192 & -1.452 & -0.850 & -0.993 & 0.335 & 0.191 \\
\hline 0.90 & 0.449 & 0.645 & 0.646 & -0.00025 & 0.0015 & -0.608 & -0.835 & -0.674 & -0.442 & -0.123 & -1.343 & -0.729 & -0.887 & 0.337 & 0.197 \\
\hline 1.00 & 0.461 & 0.676 & 0.653 & -0.00022 & 0.0020 & -0.768 & -0.978 & -0.834 & -0.603 & -0.303 & -1.476 & -0.873 & -1.032 & 0.335 & 0.196 \\
\hline 1.50 & 0.505 & 0.657 & 0.625 & -0.00008 & 0.0015 & -1.306 & -1.460 & -1.361 & -1.158 & -0.981 & -2.137 & -1.406 & -1.594 & 0.322 & 0.188 \\
\hline 2.00 & 0.531 & 0.486 & 0.479 & 0.00056 & 0.0015 & -1.516 & -1.651 & -1.569 & -1.368 & -1.230 & -2.303 & -1.597 & -1.749 & 0.314 & 0.194 \\
\hline 2.50 & 0.572 & 0.428 & 0.396 & 0.00019 & 0.0010 & -1.781 & -1.880 & -1.829 & -1.653 & -1.527 & -2.475 & -1.853 & -2.046 & 0.308 & 0.182 \\
\hline 3.00 & 0.611 & 0.456 & 0.422 & 0.00003 & 0.0010 & -2.200 & -2.267 & -2.246 & -2.082 & -1.953 & -2.852 & -2.267 & -2.461 & 0.314 & 0.184 \\
\hline 4.00 & 0.612 & 0.268 & & 0.00063 & 0.0015 & -2.207 & -2.237 & -2.241 & -2.131 & -2.018 & -2.892 & -2.242 & -2.385 & 0.288 & 0.185 \\
\hline 5.00 & 0.605 & 0.077 & 0.066 & 0.00093 & 0.0015 & -2.093 & -2.142 & -2.122 & -2.022 & -1.917 & -2.796 & -2.143 & -2.283 & 0.270 & 0.185 \\
\hline$T$ & 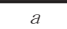 & $h_{\text {sub }}$ & 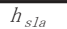 & $b$ & $d$ & $c_{0}$ & $c_{700}$ & $c_{\mathrm{I}}$ & $c_{\text {II }}$ & $c_{\text {III }}$ & $c_{3000}$ & $c_{500}$ & $c_{900}$ & $e$ & error \\
\hline 0.07 & 0.592 & 0.387 & 0.558 & -0.00531 & 0.0025 & -0.402 & -0.683 & -0.403 & -0.355 & -0.320 & -0.768 & -0.506 & -0.707 & 0.323 & 0.177 \\
\hline 0.10 & 0.584 & 0.420 & 579 & -0.00488 & 0.0025 & -0.442 & -0.702 & -0.456 & -0.366 & -0.318 & -0.804 & -0.561 & -0.738 & 0.307 & 0.164 \\
\hline 0.15 & 0.529 & & & -0.00362 & 0.0020 & -0.230 & -0.454 & -0.263 & -0.100 & -0.066 & -0.595 & -0.359 & -0.527 & 0.294 & \\
\hline 0.20 & 0.512 & 0.308 & 0.432 & -0.00347 & 0.0035 & 0.004 & -0.228 & -0.031 & 0.129 & 0.215 & -0.391 & -0.109 & -0.267 & 0.285 & 0.150 \\
\hline 0.25 & 0.501 & & & & 0.0035 & 0.032 & -0.1 & -0.004 & 0.140 & & -0.425 & -0.070 & -0.197 & 0.288 & 0.150 \\
\hline 0.30 & 0.482 & 0.253 & 0.316 & -0.00284 & 0.0040 & 0.197 & 0.024 & 0.161 & 0.294 & 0.507 & -0.337 & 0.104 & -0.049 & 0.281 & 0.145 \\
\hline 0.40 & 0.474 & & & & & -0.002 & & -0.037 & 0.072 & 0.332 & -0.483 & & & 0.261 & 0.142 \\
\hline 0.50 & 0.494 & 0.323 & 0.317 & -0.00209 & 0.0045 & -0.175 & -0.294 & -0.209 & -0.111 & 0.174 & -0.604 & -0.243 & -0.423 & 0.265 & 0.151 \\
\hline 0.60 & 0.496 & & & & & & & -0.395 & & -0.067 & -0.834 & & & 0.276 & 0.171 \\
\hline 0.70 & 0.514 & 0.385 & 0.382 & -0.00111 & 0.0045 & -0.675 & -0.805 & -0.702 & -0.612 & -0.400 & -1.149 & -0.703 & -0.824 & 0.282 & 0.180 \\
\hline 0.80 & 0.520 & & & -0.00091 & 0.0040 & -0.898 & & -0.920 & -0.838 & -0.684 & -1.388 & -0.920 & -1.054 & 0.289 & 0.184 \\
\hline 0.90 & 0.515 & 0.462 & 420 & -0.00054 & 0.0040 & -0.935 & -1.059 & -0.953 & -0.880 & -0.767 & -1.418 & -0.951 & -1.077 & 0.291 & 0.187 \\
\hline 1.00 & 0.515 & & & -0.00018 & 0.003 & -1.051 & -1.166 & -1.069 & -0.992 & & -1.503 & & -1.180 & 0.290 & 0.184 \\
\hline 1.50 & 0.496 & 0.271 & 0.260 & 0.00083 & 0.0025 & -0.996 & -1.113 & -1.012 & -0.926 & -0.969 & -1.558 & -0.998 & -1.076 & 0.288 & 0.175 \\
\hline 2.00 & 0.533 & & & & & & & -1.315 & -1.233 & & & & & 0.283 & \\
\hline 2.50 & 0.584 & 0.176 & 0.183 & 0.00127 & 0.0020 & -1.833 & -1.887 & -1.852 & -1.770 & -1.774 & -2.274 & -1.816 & -1.988 & 0.275 & 0.174 \\
\hline 3.00 & 0.610 & 0.251 & 0.233 & 0.00103 & 0.0020 & -2.200 & -2.234 & -2.226 & -2.135 & -2.072 & -2.675 & -2.191 & -2.369 & 0.269 & 0.172 \\
\hline 4.00 & 0.662 & 0.101 & 0.067 & 0.00022 & 0.0025 & -2.416 & -2.438 & -2.430 & -2.381 & -2.340 & -2.932 & -2.400 & -2.538 & 0.242 & 0.160 \\
\hline 5.00 & 0.702 & 0.092 & 0.070 & 0.00020 & 0.0040 & -2.834 & -2.835 & -2.843 & -2.820 & -2.754 & -3.307 & -2.810 & -2.918 & 0.229 & 0.158 \\
\hline
\end{tabular}

$\triangle \quad--$ - Radial

$\nabla \quad \cdots . . .$. Transverse

O Vertical
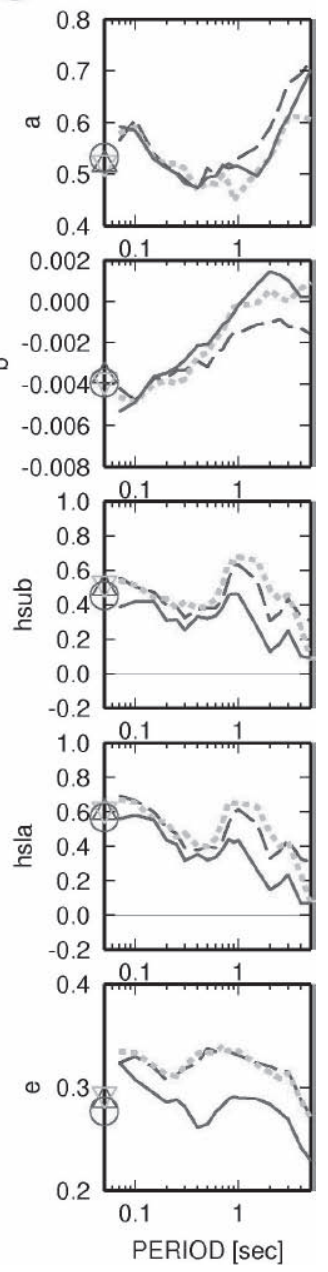

図 7 フィリピン海プレ 一トの海溝型地震の加速 度応答スペクトルと最大 加速度の回帰係数

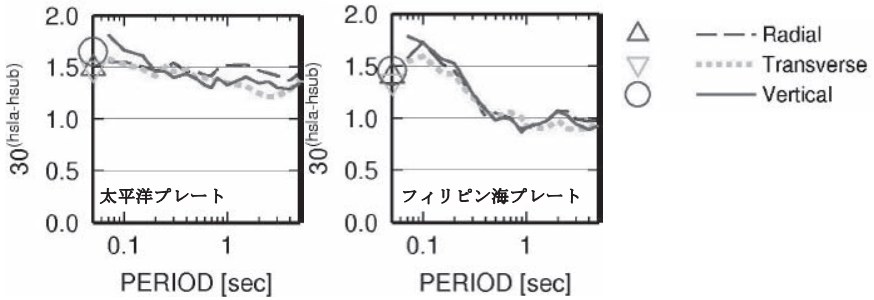

図 8 回帰係数 $h_{\text {sla }} 、 h_{\text {sub }}$ に基づく震源深さ $30 \mathrm{~km}$ の場合のプレー 卜境界地震に対するスラブ内地震の加速度応答スペクトルの比

と比較して火山フロント直下及び背弧側の $Q$ 值が大きく、これが影 響しているものと考えられる。Vertical 成分では、図中に観測点名を 示した地点などでの観測最大加速度が大きいが、これらの観測点で は他の地震でも最大加速度が大きくなっている。例として、2005 年 宮城県沖地震 $(M w 7.1)$ と 2000 年鳥取県西部地震 $(M w 6.7)$ の Vertical 成 分の観測最大加速度と、本研究及び地壳内地震に対する佐藤 ${ }^{7)}$ の距 離減衰式との比較を図 11 に示す。図 10 に観測点名を示した地点の うち、2003 年宮城県沖地震の際に非常に大きな最大加速度となった MYG011 は、2004 年 1 月に移設された。また、2005 年宮城県沖地

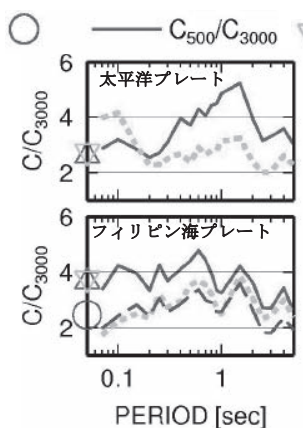

$\begin{array}{lll}\text { (a) Radial } & \text { (b) Transverse } & \text { (c) Vertical } \\ \text { 园 } & V s 3000 \mathrm{~m} / \mathrm{s} \text { 程度の地震基盤に対する地盤増幅率 }\end{array}$

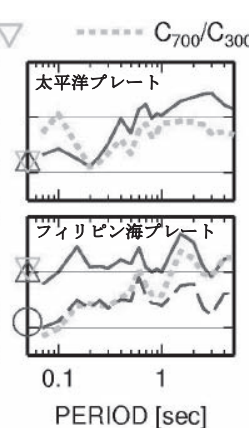

$\begin{array}{lll}\text { (a) Radial } & \text { (b) Transverse } & \text { (c) Vertical } \\ \text { 园 } & V s 3000 \mathrm{~m} / \mathrm{s} \text { 程度の地震基盤に対する地盤増幅率 }\end{array}$

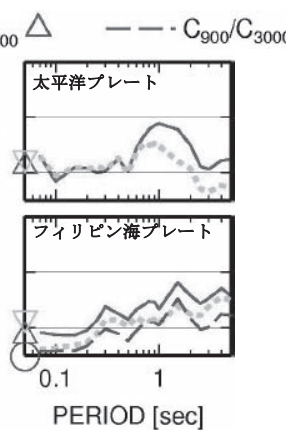

震の際には、IWTH21 では記録が得られていない。IWTH02、IWTH04 では、2003 年と 2005 年の宮城県沖地震でともに大きく、HRSH01 と HRSH03 では、2001 年芸予地震と 2000 年鳥取県西部地震でとも に大きい。

図 12 には、これら 4 観測点での加速度応答スペクトルと最大加速 度の地震基盤からの地盤増幅率(全継続時間の Vertical 成分)を示す。 いずれの観測点でも最大加速度の増幅率は 10 倍以上であり、短周期 

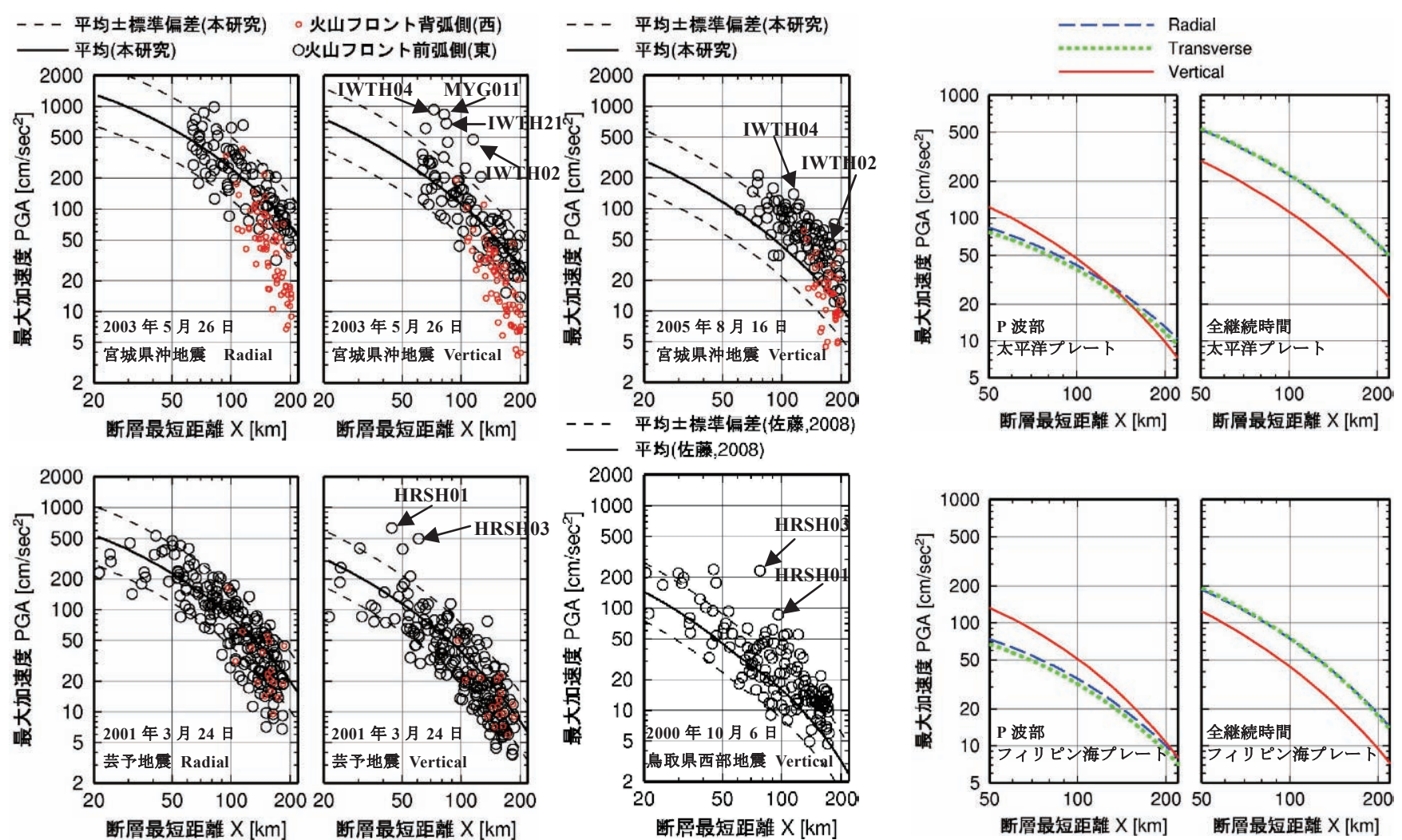

図 102003 年 5 月 26 日宮城県沖地震と 2001 年 3 月 24 日芸予地震の観測最大加速度と本研究の距離 減衰式の比較

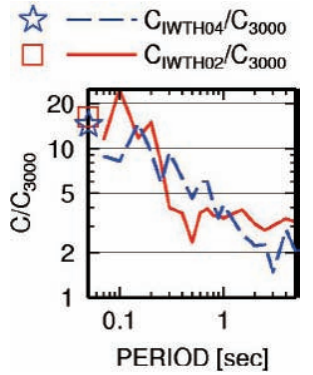

図 12 IWTH02、IWTH04、HRSH01、HRSH03 での地震基盤からの 地盤増幅率(全継続時間の Vertical 成分)

で増幅率が大きい。2003 年宮城県沖地震の震源近傍の水平動の最大 加速度が大きい原因として、震源での短周期の励起が大きかったこ とと、震源近傍の三陸海岸付近の観測点では硬い層の上に薄い軟弱 層が堆積しているため、短周期領域での地盤増幅が大きかったこと が指摘されている ${ }^{32}$ が、上下動についても同じ解釈ができる。 $\mathrm{Satoh}^{47)}$ は、1978 年から 2005 年までの Mw5.5 以上の日本のプレート 境界地震の中で、2005 年宮城県沖地震の $B r u n e^{33)}$ の応力降下量が最 大、1978 年宮城県沖が 2 番目に大きいことを指摘している。2005 年宮城県沖地震の上下動の観測最大加速度が距離減衰式の平均值よ り大きいという結果はこの研究と整合する。より精度よい予測のた めには、地域性を考虑することが必要であると考えられる。

図 13 には、両プレートのデータセットの範囲内の $M w 7.4$ 、震源深 さ $60 \mathrm{~km}$ のスラブ内地震に対する $V s 600 \sim 800 \mathrm{~m} / \mathrm{s}$ の基盤 $\left(c_{700}\right.$ を用い た場合)での $\mathrm{P}$ 波部と全継続時間に対する最大加速度の距離減衰式 を示す。水平 2 成分の違いは小さい。P 波部では、遠方で 3 成分が 近づく傾向があるのに対して、全継続時間では 3 成分がほぼ平行で
ある。これは、地殼内地震に対する距離減衰式 7) と同じ特徴である。 $\mathrm{P}$ 波部ではプレートによる違いが小さいが、全継続時間では太平洋 プレートの地震の方が最大加速度が大きい。

図 14 には、同じ条件での本研究と既往の研究の最大加速度の距離 減衰式の比較を水平成分(本研究では Radial 成分) と Vertical 成分につ いて示す。ここで用いた片岡・他 ${ }^{36)}$ の式は、震源深さをパラメータ とした場合であり、Kanno et al. ${ }^{45}$ の式は火山フロントの影響を考慮 しない場合である。司・翠川 ${ }^{18}$ は水平 2 成分のうち大きい方、Kanno et al. ${ }^{45)}$ と片岡・他 ${ }^{36}$ 怯水平 2 成分のベクトル合成值であるため、水 平 2 成分独立や平均の場合より大きくなる。地盤条件も、Kanno et al. ${ }^{45)}$ では地下 $30 \mathrm{~m}$ までの平均 $\mathrm{S}$ 波速度 Avs $30=700 \mathrm{~m} / \mathrm{s}$ に補正、Zhao et al. ${ }^{19)}$ は岩盤 $(600 \mathrm{~m} / \mathrm{s}<\mathrm{Avs} 30<1100 \mathrm{~m} / \mathrm{s})$ 、片岡・他 ${ }^{36)}$ と本研究はVs 600 $\sim 800 \mathrm{~m} / \mathrm{s}$ の基盤という違いがある。司・翠川 ${ }^{18)}$ の距離減衰式は、岩 盤上の記録は 1.4 倍して地盤上に補正して作成されているため、 1.4 で割って岩盤相当に補正した。本研究の距離減衰式は太平洋プレー トの方がフィリピン海プレートより 2.5 倍程度大きく、既往の距離 減衰式はこの間にある。また、火山フロントの前弧側の記録のみを 用いた本研究の距離減衰の傾きは、Kanno et al. ${ }^{45)}$ 、Zhao et al. ${ }^{19)}$ より 小さい。Kanno et al. ${ }^{45)}$ の式に、火山フロントの影響を考慮する ${ }^{45), 46)}$ と、さらに距離減衰は大きくなる。司・翠川 ${ }^{18)}$ の式の距離減衰の傾 きは本研究と同程度に小さいが、これは、司・翠川 ${ }^{18)}$ では既往の距 離減衰式に基づき地款内地震、プレート境界地震、スラブ内地震に 共通の距離減衰の傾き与えているためと考えられる。同じ条件での 本研究と既往の研究の最大速度の距離減衰式(水平成分)を比較した 場合も、近距離では太平洋プレートの方がフィリピン海プレートよ 


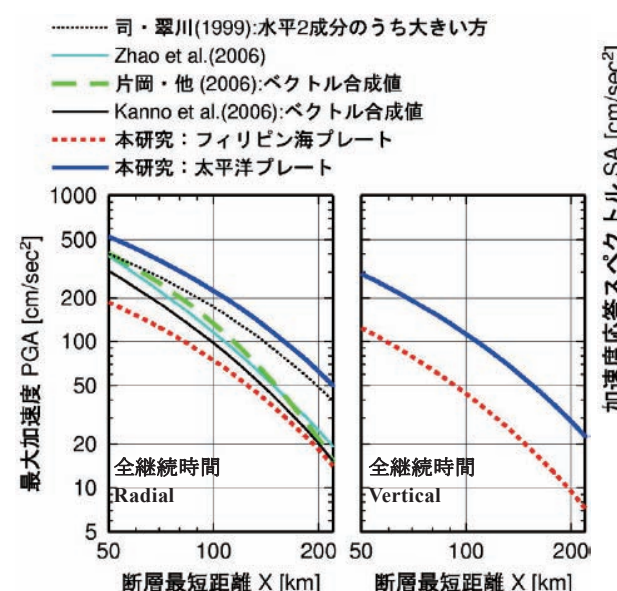

図 $14 \quad M w 7.4$ 、震源深さ $60 \mathrm{~km}$ のスラブ内地震に 対する本研究と既往の研究の最大加速度の距離減 衰式の比較 $(V s 600 \sim 800 \mathrm{~m} / \mathrm{s}$ の基盤相当に補正)

り 2.5 倍程度大きく、既往の距離減衰式 ${ }^{18), 19), 36)}$ はこの間にあった。 この比較の際、司・翠川 ${ }^{18)}$ の最大速度の距離減衰式は、松岡・翠川 ${ }^{48)}$ の式に基づき Avs $30=700 \mathrm{~m} / \mathrm{s}$ に補正した。

図 15 には、本研究と既往の研究の距離減衰式に基づく加速度応答 スペクトルの比較を示す。 $M w 7.4$ で、(a)は震源深さ $60 \mathrm{~km}$ 、断層最 短距離 $60 \mathrm{~km}$ のスラブ内地震、(b)は、震源深さ $35 \mathrm{~km}$ 、断層最短距離 $35 \mathrm{~km}$ のプレート境界地震の例である。Mw7.4 は、フィリピン海プ レートのプレート境界地震の最大 $M w$ より大きいが、回帰式ではス ラブ内地震とプレート境界地震のマグニチュード係数 $a$ は同じと考 えているため適用範囲内である。Vs600〜 $800 \mathrm{~m} / \mathrm{s}$ の基盤相当に補正 している。水平 2 成分のベクトル合成值は、水平 2 成分独立な場合 に比べて $1.2 \sim 1.5$ 倍程度大きくなること㿣を考慮すると、本研究の スラブ内地震に対する太平洋プレートとフィリピン海プレートに対 する式の間に既往の式があるといえる。規模の大きなスラブ内地震 では、太平洋プレートの地震の方がフィリピン海プレートの地震よ り地震動が大きいという結果は、Asano et al. ${ }^{17)}$ や池田・他 ${ }^{12)}$ とも定 性的に整合する。プレート境界地震でも、太平洋プレートの地震の 方がフィリピン海プレートの地震より大きいが、その違いはスラブ 内地震と比較して小さい。スラブ内地震とプレート境界地震の違い と震源深さ依存性が考慮されている Zhao et al. ${ }^{199}$ の式は、本研究の太 平洋プレートの距離減衰式と近い。本研究の距離減衰式に基づく最 大加速度、最大速度、ごく一部の周期を除く加速度応答スペクトル は、両データセットに共通な $M w 7 \sim 7.4$ の近距離では、プレート境 界地震、スラブ内地震の水平動・上下動とも、フィリピン海プレー トより太平洋プレートの地震の方が大きかった。

\section{6. まとめ}

本研究では、太平洋プレートとフィリピン海プレートのスラブ内 地震・プレート境界地震の 3 成分 (Radial成分、Transverse 成分、Vertical 成分)の地震動強さ (最大加速度、最大速度、減衰定数 $5 \%$ の加速度応 答スペクトル)の距離減衰式を構築した。 $M w$ と断層最短距離と震源 深さ $D$ をパラメータとし、種々のサイト特性が考慮されている。本 研究で得られた距離減衰式(全継続時間) と、距離減衰式を通して導 かれた日本の海溝型地震の地震動の性質について以下にまとめる。

(1) はぎとり解析に基づき $V s 3000 \mathrm{~m} / \mathrm{s}$ 程度の地震基盤でのサイト係
数を求めており、本研究の距離減衰式では、地震基盤からの増 幅率も得られる。また、入力動として用いることができるよう に、Vs400〜600m/s、Vs600〜800m/s、Vs $800 \sim 1000 \mathrm{~m} / \mathrm{s}$ の基盤で のサイト係数も算出した。

(2) 本研究では、既往の研究とは異なり、地震動レベルが $D^{h}$ に比例 するという回帰モデルを用いた。最大加速度や加速度応答スペ クトルの短周期領域での回帰係数 $h$ は $2 / 3$ 前後の值となり、こ れは、Coulomb-Mohr の式と $\omega^{-2}$ モデルから解釈できる。

(3) 同じプレートのスラブ内地震とプレート境界地震の回帰係数 $h$ は類似の傾向をもつが、同じ震源深さではスラブ内地震の方が プレート境界地震より地震動レベルが大きい距離減衰式が得ら れた。プレート境界地震に対するスラブ内地震の比は、データ セットの震源深さの平均值を用いた場合には、最大加速度や加 速度応答スペクトルの短周期領域において、太平洋プレートで は2.8〜2.9 倍、フィリピン海プレートでは 1.5〜1.6 倍となった。

(4) $M w 7 \sim 7.4$ の近距離では、スラブ内地震とプレート境界地震とも、 ごく 1 部の周期を除き、太平洋プレートの方がフィリピン海プ レートより、水平動、上下動とも大きい。既往の水平動に対す る距離減衰式の地震動強さは、本研究の太平洋プレートとフィ リピン海プレートの距離減衰式のほぼ中間に位置している。

(5) 断層最短距離 $250 \mathrm{~km}$ 以下の火山フロント前弧側のデータのみを 用いたため、既往の距離減衰式と比較して距離減衰の傾きが小 さい(減衰が小さい)。

はじめにでも述べたように、これまで、 $M_{J} 7$ 以上の規模の大きい 海溝型地震を含むデータセットで、日本のスラブ内地震とプレート 境界地震を区別した上下動の距離減衰式が作成された例がなかった。 したがって、本研究の距離減衰式は、上下動も考慮した重要構造物 の耐震安全性評価のための入力地震動や、半経験的手法や理論的手 法に基づく強震動予測波形の検証用として有用であると考えられる。 ただし、フィリピン海プレートのプレート境界地震は日向灘の地震 のみ、スラブ内地震は日向灘の地震と紀伊半島南東沖の地震がほと んどであるため、これらの地震の特徵が強く出ている可能性がある ことに注意が必要である。

\section{謝辞}

本研究は、科学研究費補助金(基盤研究(c)課題番号 20560544)によ る成果である。本研究では、建築研究所の広尾町役場の強震記録、 防災科学技術研究所の K-NET、KiK-net 強震記録・地盤構造の情報・ 
F-net のメカニズム解、気象庁の 87 型強震記録・震源情報、Harvard 大学のメカニズム解、図の作成には $\mathrm{GMT}^{50)}$ を用いました。また、查 読者のご意見は非常に有益でした。記して感謝致します。

\section{参考文献}

1) Chiou, B., Darragh, R., Gregor, N. and Silva, W. : NGA Project strong-motion database, Earthquake Spectra, Vol.24, No.1, pp.23-44, 2008

2) Abrahamson, N., Atkinson,G., Boore, D., Bozorgnia, Y., Campbell, K., Chiou, B., Idriss, I.M., Silva, W. and Youngs, R. : Comparisons of the NGA ground-motion, Earthquake Spectra, Vol.24, No.1, pp.45-66, 2008

3) 高橋克也, 武村雅之, 藤堂正喜, 渡辺孝英, 野田静男 : 様々な岩盤上での強震動応 答スペクトルの予測式, 第 10 回日本地震工学シンポジウム, pp.547-552, 1998

4) 西村利光, 堀家正則 : 強震ネットワーク $(\mathrm{K}-\mathrm{NET})$ データから推定した水平・上下最 大加速度の距離減衰式, 日本建築学会構造系論文集, 第 571 号, pp.63-70, 2003.9

5) 堀家正則, 西村利光 : 強震ネットワーク(K-NET)データから推定した水平動と上下 動の最大速度距離减衰式, 日本建築学会構造系論文集, 第 575 号, pp.73-79, 2004.1

6) 原子力安全委員会 : 発電用原子炉施設に関寸る而震設計審査指針, (オンライン), 入手先<http://www.nsc.go.jp/anzen/sonota/kettei/20060919-31.pdf>, (参照 2007.10.3)

7) 佐藤智美：地款内地震に対する $\mathrm{P}$ 波部・ $\mathrm{S}$ 波部・全継続時間の水平・上下動の距 離減衰式, 日本建築学会構造系論文集, 第 632 号, pp.1745-1754, 2008.10

8) 武村雅之 : 1993 年釧路沖地震の発生メカニズムと地震動-やや深溌地震による強震 動の特徵-, 第 21 回地盤震動シンポジウム, 日本建築学会, pp.3-14, 1993.11

9) 加藤研一, 武村雅之, 八代和彦 : 強震記録から評価した短周期震源スペクトルの地 域性, 地震 第 2 輯, 第 51 巻, pp.123-138, 1998

10) 佐藤智美 : 中小地震の応力降下量の断層タイプ・震源深さ依存性及び地域性に関 寸る研究, 土木学会地震工学論文集, CD-ROM,p_048.pdf, 2003

11) 川瀬 博, 松尾秀典: K-NET, KiK-net, JMA 震度計観測網による強震動波形を用い た震源・パス・サイト各特性の分離解析, 日本地震工学会論文集, 第 4 巻, 第 1 号, pp.33-52, 2004

12) 池田孝, 武村雅之, 加藤研一 : 強震記録に基づくフィリピン海プレート内で発生す るスラブ内地震の高振動数成分の励起特性-北海道・東北地方のスラブ内地震との 比較-,日本建築学会構造系論文集, 第 586 号, pp.53-61, 2004.12

13) 笹谷努, 森川信之, 前田宜浩 : スラブ内地震の震源特性, 北海道大学地球物理学研 究報告, Vol.69, pp.123-134, 2006

14) 中村亮一 : 短周期地震動記録に基づく日本列島下の三次元減衰構造 Qs ・震源スペ クトル・地盤増幅の同時インバージョンとその応用, 博士論文 東京大学大学院理 学系研究科, 2009.3

15) 佐藤智美, 巽誉樹 : 全国の強震記録に基づく内陸地震と海溝性地震の震源・伝播 ・ サイト特性, 日本建築学会構造系論文集, 第 556 号, pp.15-24, 2002.6

16) Asano, K., Iwata, T. and Irikura, K. : Source characteristics of shallow intraslab earthquakes derived from strong motion simulations, Earth Planets Space, Vol.55, e5-e8, 2003

17) Asano, K., Iwata, T. and Irikura, K. : Characterization of source models of shallow intraslab earthquakes using strong motion data, Proc. 13th World Conf. Earthq. Eng., Vancouver, Canada, Paper No. 835, 2004

18) 司宏俊, 翠川三郎 : 断層タイプ及び地盤特性を考慮した最大加速.度・最大速度の距 離减衰式, 日本建築学会構造系論文集, 第 523 号, pp.63-70, 1999.9

19) Zhao, X.G., Zhang, J., Asano, A., Ohno, Y., Oouchi, T., Takahashi, T., Ogawa, H., Irikura, K., Thio, K.H., Somerville, P., Fukushima, Y. and Fukushima, Y. : Attenuation relations of strong ground motion in Japan using site classification based on predominant period, Bull. Seism. Soc. Am., Vol.96, pp.898-913, 2006

20) 福島美光, 田中貞二：新しいデータベースを用いた最大加速度の距離减衰式の改 訂, 日本地震学会講演予稿集, No. 2,pp.116, 1992

21) 筧楽麿, 西條裕介 : 2003 年宮城県沖スラブ内地震による強震動と東北日本弧の減 衰構造, 第 12 回日本地震工学シンポジウム, 0025, 2006

22) 地震調査研究推進本部: 海溝型地震の長期評価, (オンライン), 入手先 $<$ http://www.jishin.go.jp/main/p hyoka02 kaiko.htm>, (参照 2007.12.27)

23) 中西一郎, 森谷武男, 笠原稔 : 1993 年釧路沖地震による被害の調査研究, pp.11-18, 1993

24) 菊地正幸, 金森博雄 : 広帯域地震記録による 1994 年北海道東方沖地震の震源メ力 ニズム, 月刊地球, Vol. 17, No. 5, pp. 322-328, 1995

25) Nakamura, W. and Takeo, M. : Slip history of the 1994 Sanriku-Haruka-Oki, Japan, earthquake deduced from strong-motion data, Bull. Seism. Soc. Am., Vol. 87, pp. 918-931,
1997

26) 青井真, 関口春子, 功刀卓, 本多亮, 藤原広行 : 近地強震動記録による宮城県沖の 地震 $(2003 / 05 / 26,18: 24)$ の震源インバージョン, (オンライン), 入手先 $<$ http://www.k-net.bosai.go.jp/k-net/news/miyagi/>, (参照 2003.8.27)

27) Koketsu, K., Hikima, K., Miyazaki, S. and Ide, S. : Joint inversion of strong motion and geodetic data for the source process of the 2003 Tokachi-oki, Hokkaido, earthquake, Earth Planets Space, Vol.56, pp.329-334, 2004

28) 国土地理院 : 2005 年 8 月 16 日宮城県沖の地震に伴う断層モデル (最終解),(オン ライン), 入手先 $<$ http://jishin.go.jp/main/chousa/05sep_miyagi/p09.htm>, (参照 2007.12.18)

29) 鈴木亘, 青井真, 関口春子 : 近地強震記録による 2008 年 7 月 24 日岩手県沿岸北部 の地震の震源インバージョン, (オンライン), 入手先<http://www.k-net.bosai.go.jp/ k-net/topics/iwate_20080724/inversion/>, (参照 2008.10.3)

30) 関口春子, 岩田知孝 : 2001 年芸予地震の破壊過程と強震動, 月刊地球 号外, No.38, pp. 239-246, 2002

31) 山中佳子 : 9 月 5 日の紀伊半島南東沖の地震 (Mj6.9, Mj7.4, Mj6.4 + Mj6.2, EIC 地震 学ノートNo.152, (オンライン), 入手先<http://wwweic.eri.u-tokyo.ac.jp/EIC/ EIC_News/EIC152.html>, (参照 2007.12.18)

32) 佐藤智美 : 強震記録に基づく 2003 年宮城県沖の地震の大加速度の成因に関する研 究, 日本建築学会構造系論文集, 第 581 号, pp.31-38, 2004.7

33) Brune, J.N. : Tectonic stress and the spectra of seismic shear waves from earthquakes, J. Geophys. Res., Vol.75, pp.4997-5009, 1970

34) McGarr, A. : Scaling of ground motion parameters, state of stress, and focal depth, J. Geophys. Res., Vol.89, pp.6969-6979, 1984

35) 日本道路協会 : 道路橋示方書・同解説 $V$ 而扵震設計編, 丸善, 2002

36) 片岡正次郎, 佐藤智美, 松本俊輔, 日下部毅明 : 短周期レベルをパラメータとした 地震動強さの距離減衰式, 土木学会論文集 A, Vol.62,pp.740-757, 2006.10

37) 藤堂正喜, 羽鳥敏明, 千葉脩, 高橋克也, 武村雅之, 田中英朗 : 堆積地盤における上 下地震動の特性と Qp 構造, 日本建築学会構造系論文集, 第475 号, pp.45-54, 1995.9

38) Ingber, L. : Very fast simulated reannealing, Math. Comp. Modeling, Vol.2, pp.967-973, 1989

39) Satoh, T. : Inversion of Qs value of deep sediments from surface-to-borehole spectral ratios considering obliquely incident SH and SV-waves, Bull. Seism. Soc. Am., Vol.96, pp.943-956, 2006

40) Gardner, G.H., Gardner, W.H., and Gregory, A.R. : Formation velocity and density - the diagnostic basics for stratigraphic traps, Geophysics, Vol.29, pp.770-780, 1974

41) 地震調査研究推進本部 : 6-2-1 O-3 地点の地下構造 H13 愛知県:三河地域堆積 平野地下構造調查, (オンライン), 入手先<http://www.hp1039.jishin.go.jp/ kozo/Aichi6B/6-2-1.htm>, (参照 2009.8.18)

42) 福島美光, 田中貞二 : 気象庁マグニチュードによる震源スペクトルのスケーリン グ則, 日本建築学会構造系論文報告集, 第425 号,pp.19-25, 1991.7

43) Yamada, N. and Iwata, T. : Long-period ground motion simulation in Kinki area during the Mj6.9 foreshock of the 2004 off Kii Peninsula earthquake, Earth Planets Space, Vol.57, pp.197-202, 2005

44) 佐藤智美 : 宮城県沖のスラブ内地震とプレート境界地震の短周期レベルの推定, 日 本地震工学会論文集, 4 巻, 第 1 号, pp.1-4, 2004

45) Kanno, T., Narita, A., Morikawa, N., Fujiwara, H. and Fukushima, Y. : A new attenuation relation for strong ground motion in Japan based on recorded data, Bull. Seism. Soc. Am., Vol.96, pp.879-897, 2006

46) 森川信之, 神野達夫, 成田章, 藤原広行, 福島美光 : 東北日本の異常震域に対応す るための最大振幅および応答スペクトルの新たな距離減衰式補正係数, 日本地震 工学会論文集, 第 6 巻, 第 1 号,pp.23-41, 2006

47) Satoh, $\mathrm{T}$ : High-stress drop interplate and intraplate earthquakes occurred off shore of Miyagi prefecture, Japan, Proc. 3rd International Symposium on the Effects of Surface Geology on Seismic Motion, Grenoble, France, pp.689-698, 2006.8

48) 松岡昌志, 翠川三郎 : 国土数值情報とサイスミックマイクロゾーニング, 第 22 回 地盤震動シンポジウム, 日本建築学会, pp.23-34, 1994

49) 佐藤智美, 片岡正次郎, 奥村俊彦 : K-Net 強震記録に基づく工学的基盤における加 速度応答スペクトルと経時特性の推定式の検討, 第 11 回日本地震工学シンポジウ ム, pp.615-620, 2002

50) Wessel, P. and Smith W.H.F. : New, improved version of Generic Mapping Tools released, EOS, AGU, 1998 